\title{
Using techno-economic modelling to determine the minimum cost possible for a microbial palm oil substitute
}

\author{
Eleni E. Karamerou', Sophie Parsons ${ }^{1}$, Marcelle C. McManus ${ }^{1}$ and Christopher J. Chuck ${ }^{2^{*}}$ (1)
}

\begin{abstract}
Background: Heterotrophic single-cell oils (SCOS) are one potential replacement to lipid-derived biofuels sourced from first-generation crops such as palm oil. However, despite a large experimental research effort in this area, there are only a handful of techno-economic modelling publications. As such, there is little understanding of whether SCOs are, or could ever be, a potential competitive replacement. To help address this question, we designed a detailed model that coupled a hypothetical heterotroph (using the very best possible biological lipid production) with the largest and most efficient chemical plant design possible.

Results: Our base case gave a lipid selling price of $\$ 1.81 / \mathrm{kg}$ for $\sim 8,000$ tonnes/year production, that could be reduced to $\$ 1.20 / \mathrm{kg}$ on increasing production to $\sim 48,000$ tonnes of lipid a year. A range of scenarios to further reduce this cost were then assessed, including using a thermotolerant strain (reducing the cost from $\$ 1.20$ to $\$ 1.15 / \mathrm{kg}$ ), zero-cost electricity $(\$ 1.12 / \mathrm{kg})$, using non-sterile conditions $(\$ 1.19 / \mathrm{kg})$, wet extraction of lipids $(\$ 1.16 / \mathrm{kg})$, continuous production of extracellular lipid $(\$ 0.99 / \mathrm{kg})$ and selling the whole yeast cell, including recovering value for the protein and carbohydrate $(\$ 0.81 / \mathrm{kg})$. If co-products were produced alongside the lipid then the price could be effectively reduced to $\$ 0$, depending on the amount of carbon funnelled away from lipid production, as long as the co-product could be sold in excess of $\$ 1 / \mathrm{kg}$.

Conclusions: The model presented here represents an ideal case that which while not achievable in reality, importantly would not be able to be improved on, irrespective of the scientific advances in this area. From the scenarios explored, it is possible to produce lower cost SCOs, but research must start to be applied in three key areas, firstly designing products where the whole cell is used. Secondly, further work on the product systems that produce lipids extracellularly in a continuous processing methodology or finally that create an effective biorefinery designed to produce a low molecular weight, bulk chemical, alongside the lipid. All other research areas will only ever give incremental gains rather than leading towards an economically competitive, sustainable, microbial oil.
\end{abstract}

Keywords: Techno-economic analysis, TEA, Single cell oil, Lipid

*Correspondence: c.chuck@bath.ac.uk

2 Department of Chemical Engineering, University of Bath, Bath BA2 7AY, UK

Full list of author information is available at the end of the article

\section{Background}

Approximately 40 million tonnes of biodiesel is currently produced globally, with the majority still produced from first-generation feedstocks, such as rapeseed, soybean or palm oil [1]. Approximately $15 \%$ of the total amount of these oils produced is now used for biodiesel. However, these feedstocks compete with land for food production and in the case of soybean and palm with virgin

c) The Author(s) 2021. This article is licensed under a Creative Commons Attribution 4.0 International License, which permits use, sharing, adaptation, distribution and reproduction in any medium or format, as long as you give appropriate credit to the original author(s) and the source, provide a link to the Creative Commons licence, and indicate if changes were made. The images or other third party material in this article are included in the article's Creative Commons licence, unless indicated otherwise in a credit line to the material. If material is not included in the article's Creative Commons licence and your intended use is not permitted by statutory regulation or exceeds the permitted use, you will need to obtain permission directly from the copyright holder. To view a copy of this licence, visit http://creativeco mmons.org/licenses/by/4.0/. The Creative Commons Public Domain Dedication waiver (http://creativecommons.org/publicdomain/ zero/1.0/) applies to the data made available in this article, unless otherwise stated in a credit line to the data. 
rainforest. The climate and biodiversity impacts posed by the use of terrestrial crop oils like palm oil and soybean oil is being increasingly understood. One potential alternative is to harness oleaginous microorganisms as a direct oil substitute, reducing the amount of vegetable oil used for biodiesel production [2-4]. Single cell oils (SCOs), are accumulated intracellularly in oleaginous microorganisms, normally under nutrient limitation and carbon excess, in a process known as de novo accumulation. Microbial lipids are typically mainly triglycerides, with a fatty acid profile similar to terrestrial vegetable oils, which makes them an attractive option for a wide range of applications from food supplements to precursors in the chemical and biofuel sectors [5, 6]. Arguably, the most heavily researched SCOs are from microalgae grown phototrophically in large outdoor raceway ponds or in photobioreactors $[7,8]$, however, after numerous commercial failures and a large body of work modelling the cost and environmental impact [9], the majority of commercial and academic interest is now invested in heterotrophic processing $[4,10]$.

As such a large body of research has been invested in developing heterotrophic SCO, with over 100 publications in 2019 alone. Over 80 yeasts have been reported to produce lipid intracellularly (over $20 \%$ of the dry weight of the cell). The majority of the work published details the use of yeast lipids for fuel production, and as such there are numerous reviews detailing the suitability of SCO for biodiesel production [11-14], with the lipid profile of most oleaginous yeast being similar to rapeseed oil. This work has demonstrated that while heterotrophic processing is technically feasible, there are still important research gaps associated with both the economic and environmental viability. For the assessment of emerging technologies at the early stages of development, technoeconomic analysis (TEA) is increasingly being used alongside life cycle assessment (LCA). This is something which is particularly common within US Department of Energy (DoE) research programmes. For example, a recent review of emerging technology assessment concluded that the use of TEA at an early technology stage is very important [15]. The use of TEA in a prospective way at low technology readiness levels (TRLs) enables the early determination of product minimum selling price, as well as understanding the key variables which effect cost and ultimately commercial viability. However, there are a number of challenges associated with doing this which include: data availability, uncertainty associated with scale-up from the laboratory, and other general uncertainties typically handled through scenario and sensitivity analysis.

Laboratory research published over the last decade for heterotrophic processing has predominately focused on improving the lipid productivity. For instance, Rhodosporidium toruloides cultivated on glucose reached $127 \mathrm{~g} / \mathrm{L}$ of cell density with $61.8 \% \mathrm{w} / \mathrm{w}$ lipid content and lipid productivity of $0.54 \mathrm{~g} / \mathrm{L} / \mathrm{h}$ under fed-batch mode, while it achieved similar oil content $(60.4 \% \mathrm{w} / \mathrm{w})$ and productivity $0.55 \mathrm{~g} / \mathrm{L} / \mathrm{h}$ under draw-fill cultivation [16]. The sugar conversion to lipids was 23 and $24 \% \mathrm{w} / \mathrm{w}$, respectively. Higher cellular density of $185 \mathrm{~g} / \mathrm{L}$ and $0.88 \mathrm{~g} / \mathrm{L} / \mathrm{h}$ lipid productivity were achieved by Rhodotorula glutinis on glucose, subjected to oxygen-enriched aeration [17]. A lipid productivity of $1.6 \mathrm{~g} / \mathrm{L} / \mathrm{h}$ was noted for the cultivation of Lipomyces starkeyi on glucose with a final $64.9 \%$ w/w oil content reported for this system [18]. Similar productivity, $1.2 \mathrm{~g} / \mathrm{L} / \mathrm{h}$ was achieved by the engineered yeast strain Yarrowia lipolytica on glucose [19]. Further work has sought to use inexpensive substrates with low or zero pre-treatment and optimisation of cultivation parameters, as well as lower cost downstream operations [20-22].

From a process engineering angle, most authors reason that since achieving high cell-density is a prerequisite for high intracellular product titres, advanced cultivation modes, such as fed-batch, draw-fill, continuous and two-stage fed-cultivations attain improved cell densities and consequently higher lipid titres [11]. Regulation of the feed rate and design of its composition delivers better carbon-to-nitrogen ratio, allowing the stoichiometric requirement of carbon flux for growth to generate lipidfree cell mass and the excess carbon to lipid synthesis [16, 23]. Multi-parameter optimisation [24, 25] and kinetic modelling approaches $[5,26]$ to identify the best operating conditions for high productivity are also under development. While there are limited reports of heterotrophic lipid production on the commercial scale [27], a number of papers have detailed pilot-scale cultivations of oleaginous yeasts at 50-300 L which provide some insight into the upscale performance $[28,29]$, including using semicontinuous processing [30].

Despite all these publications, reviews, perspectives and insights, there is no clear indication of whether a heterotrophic process is even economically feasible, especially in the replacement of lower value lipids necessary for biodiesel production. As opposed to algal modelling, only a handful of techno-economic studies have dealt with the design of a microbial lipid production plant, with predicted prices being between $\$ 1.72-\$ 5.9 / \mathrm{kg}[27$, $31,32]$.

All of these studies demonstrated a far higher lipid selling price than that of conventional oils, discouraging progress on taking heterotrophic processes to scale, and from this it looks unlikely that SCO grown heterotrophically could compete with plant oils which are sold for between $\$ 0.5-1.9 / \mathrm{kg}[34,35]$ (Table 1). All 
Table 1 Prices for common vegetable oils in October 2019 ( source: Indexmundi [33])

\begin{tabular}{ll}
\hline Vegetable oil & Price $\mathbf{( \$ / \mathbf { t } )}$ \\
\hline Soybean & 776 \\
Rapeseed & 909 \\
Sunflower & 771 \\
Palm & 591 \\
\hline
\end{tabular}

of these studies demonstrate that there are large cost impacts in the upstream (cost of raw materials), midstream (bioreactor-associated utilities) and as lipids are synthesised intracellularly, the need for cell disruption increases the complexity and costs of the downstream processing stages as well [36]. The sensitivity analysis demonstrates that rather than a single aspect, almost all parts of the process have a combined impact, demonstrating that there is no simple chemical engineering fix to reduce the price. However, in all of the above work, the processes are modelled on real microbes, with experimentally determined growth kinetics. Despite these studies being a suitable guide as to what could feasibly achieved with the current organisms and sensible plant design, they do not demonstrate which scientific advances in key areas would go the furthest in making SCO competitive.

Therefore, there is a key knowledge gap of what is absolutely the lowest price that lipid could be produced for. As there are biological limits to how much lipid can be produced from a unit of sugar and engineering limits to the scale that the lipids can be produced on, it is theoretically possible to determine this absolute minimum. This is vital in this area to determine firstly whether there is any point continuing research into $\mathrm{SCO}$ production for biofuels, and secondly what areas should be specifically targeted to reduce the price effectively. To this end, in this study, we use a novel approach to produce a prospective assessment, not to produce a techno-economic model that demonstrates what is plausible, or even what is feasible at this early stage, but one to investigate the absolute lowest possible minimum lipid selling price if a biological system was run to its theoretical maximum, in a chemical plant that was designed to be the most effective possible. This is the first time that this has been demonstrated for lipid production and the aim is therefore not to show at what lipids could be produced for, but what the price of lipid is where no possible scientific advance in heterotrophic cultivation could deliver a cheaper lipid, and by extension what areas in SCO production should be heavily researched as being the most effective way of producing a competitive SCO.

\section{Results and discussion}

\section{Cultivation workflow description}

In our hypothetical process, a single cultivation lasts for 28 days, with the batch growth phase lasting for 2 days and the rest dedicated to draw-fill operation with daily harvesting. In particular, at the end of the batch and every $24 \mathrm{~h}, 30 \%$ of the broth is removed and replaced with fresh medium. Addition of fresh medium creates gradients of $\mathrm{pH}$, temperature and nutrient concentrations, which need to be absorbed as soon as possible to avoid stressing and lag phase of the microorganisms. At large scale restoration of the cultivation conditions cannot happen within minutes so the harvest/refill volume was limited to the $30 \%$ of the bioreactor working volume [30]. On the last day of the cultivation, the whole content of the reactor was emptied and processed. Cell concentration was assumed to be maintained at $185 \mathrm{~g} / \mathrm{L}$ with an oil content of $60.4 \% \mathrm{w} / \mathrm{w}$ and the lipid profile was assumed to be similar to palm oil. The air flowrate was assumed to be $0.5 \mathrm{vvm}$. With an overall growth rate of $63.58 \mathrm{~g} / \mathrm{L} / \mathrm{d}$, the $44.4 \mathrm{t} /$ day of cells needed to level the concentration to $185 \mathrm{~g} / \mathrm{L}$ are generated. The plant operates for $8400 \mathrm{~h} /$ years (350 days) in a 24-h basis and the production was designed based on the annual sugar supply (which we assumed to be stored after the growing season to allow all year-round operation of the plant).

The sugars obtained from the circular area in Sao Paulo are far in excess for use in one $1000-\mathrm{m}^{3}$ reactor under these conditions and so do not limit the production for a single bioreactor system. Between each cultivation cycle, $3 \mathrm{~h}$ were allowed for cleaning-in-place and loading and uploading for $8 \mathrm{~h}$ each with a $100 \mathrm{~m}^{3} / \mathrm{h}$ rate. The time required to withdraw and refill the $30 \%$ of the broth was also taken into account. All unit operations downstream to the bioreactor were assumed to operate in continuous mode. From the lipid yield on sugars the required amount of sugar needed was calculated. The fermentation workflow and the cultivation details are depicted in Table 2.

\section{Detailed description of the plant equipment}

The process flow diagram (PDF) for the process is depicted in Fig. 1. The process is structured in two areas, Area 100: upstream and cultivation (media preparation, sterilisation, bioreactor and associated utilities) and Area 200: downstream (cell harvesting and lipid recovery).

It was modelled so that the nutrients (sugars, ammonium sulphate and water) were mixed in a mixing tank V-101 to form a concentrated solution which was later diluted with the required amount of water to reach the final concentration of nutrients through an in-line mixer (M-101). It was calculated that the medium was then 
Table 2 Operation workflow and microbe details

\begin{tabular}{ll}
\hline Yeast-related properties & \\
\hline Mode of operation & Draw-fill \\
\hline Maximum DCW $(\mathrm{g} / \mathrm{L})$ & 185 \\
Lipid content $(\% \mathrm{w} / \mathrm{w})$ & 60.4 \\
Lipid productivity $(\mathrm{g} / \mathrm{L} / \mathrm{h})$ & 1.6 \\
Temperature $\left({ }^{\circ} \mathrm{C}\right)$ & 30 \\
Workflow details & \\
Working volume $\left(\mathrm{m}^{3}\right)$ & 800 \\
Clean-in-place $(\mathrm{h})$ & 3 \\
Uploading/unloading time $\left(\mathrm{m}^{3} / \mathrm{h}\right)$ & 100 \\
Fermentation $(\mathrm{h})$ & 672 \\
Harvest volume $(\% \mathrm{v} / \mathrm{v})$ & $30 \%$ \\
Number of harvests & 27 \\
Plant operation details & \\
Plant operation (h/year) & 8400 \\
Number of fermentations/year & 10 \\
Run time per cycle $(\mathrm{h} / \mathrm{cycle})$ & 820.6 \\
Mass of microbial oil (t/year) & 8052.47
\end{tabular}

transferred to the continuous steriliser. The steriliser consisted of three parts [37]: HE-101 is the pre-heating section of the steriliser where the incoming media exchange heat with the sterile media going into the reactor which in turn are cooled to $30{ }^{\circ} \mathrm{C}$, the heating section HE-102 where the media reach the sterilisation temperature $120{ }^{\circ} \mathrm{C}$, which is maintained at the holding tube of the steriliser (HT-101), where the media remained for $2 \mathrm{~min}$. The sterile media was then cooled down in HE-101 and are transferred with the aid of a pump P-102 to the bioreactor R-101.

$23,000 \mathrm{~m}^{3} / \mathrm{h}$ of air was supplied through a centrifugal compressor $\mathrm{C}-101$, necessary to supply the large amount of air required. The temperature of the broth was then maintained at $30{ }^{\circ} \mathrm{C}$ with external cooling via recirculation. The harvested broth passed through a pasteuriser HE-201, where the cells are deactivated for $60 \mathrm{~min}$ at $65{ }^{\circ} \mathrm{C}$, this was put in to ensure stability through all downstream operations and storage. After pasteurisation the broth was kept in a set of holding tanks (in order to be processed at a suitable rate). The cells were then separated from the broth with a vacuum rotary filter, RF-201, which has a filtration rate of $100 \mathrm{~m}^{3} / \mathrm{h}$. The yeast cake

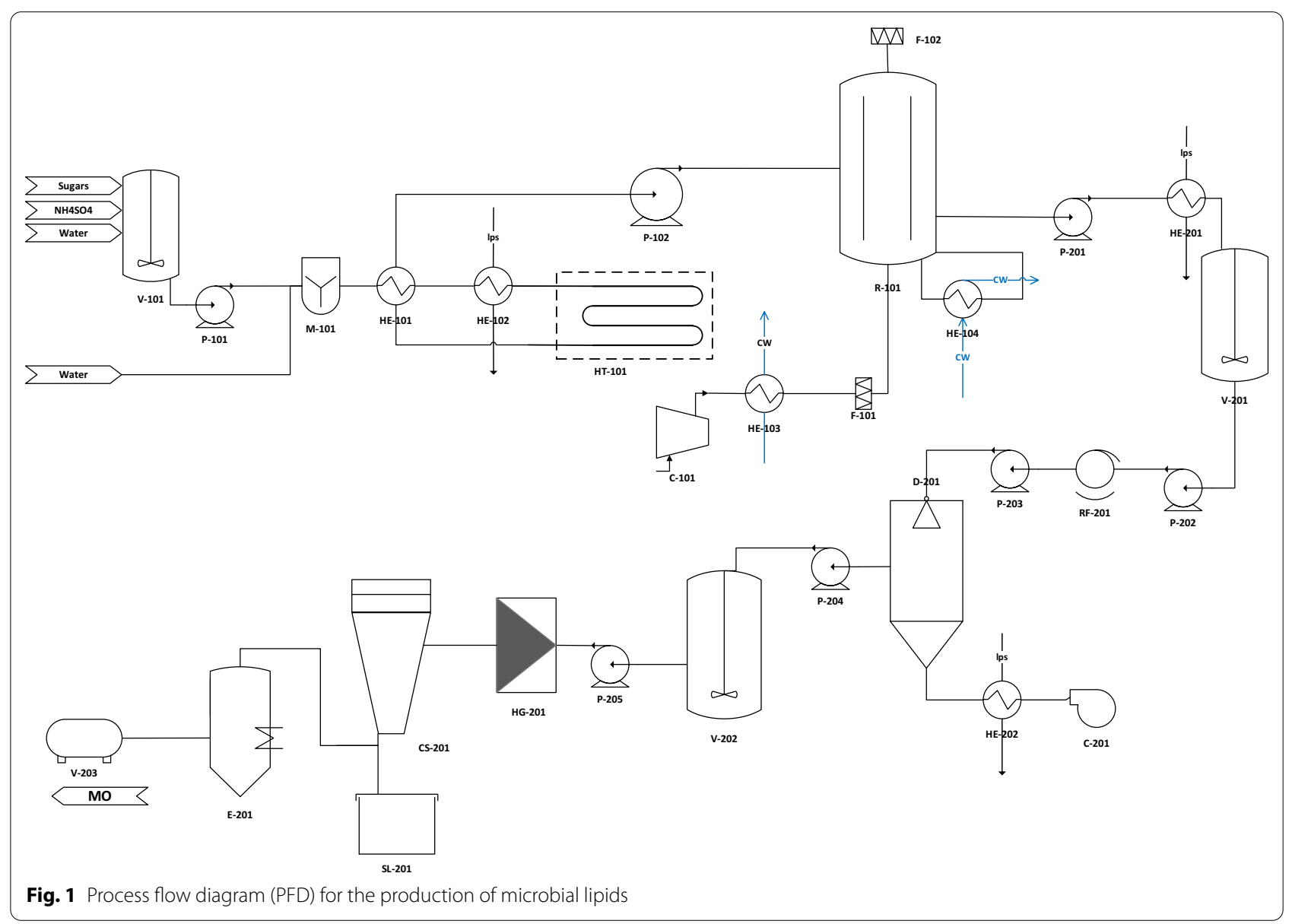


was then treated in a spray dryer (D-201), which dries the yeast paste from an assumed moisture content of $35 \%$ [38] to 5\% [39]. After that the dried yeast was mixed with hexane in a mixing tank V-202 at a ratio of $25 \%$ yeast mass to hexane $[27,31]$ and then homogenised in a high-pressure homogeniser HG-201. The lysed cells were separated from the lipids and hexane in a centrifugal separator (CS-201), stored in a silo (SL-201) and then the hexane was recovered in a single-effect evaporation unit (E-201). The resulting lipids were then assumed to be kept for a short period of time in a holding tank (V-203), from where they are transported to the buyer.

\section{Single bioreactor microbial lipid production facility}

From the circular area in Brazil 254,981.14 t/year sugars can be obtained. In the model for a single bioreactor $8052.49 \mathrm{t}$ of microbial lipids are produced per year. The lowest cost of sucrose that was found in the literature was $\$ 0.14 / \mathrm{kg}$ and so this value was used throughout [28]. The equipment and utility costs associated to this capacity are presented in Tables 3 and 4 and the raw materials cost in Table 5 . The FCI reached $\$ 16,085,855$. The fermentationrelated installed equipment cost was $36 \%$ of the total installed equipment cost in contrast to other works with more bioreactors. The airlift bioreactor itself constitutes $8 \%$ of the installed equipment cost. The bioreactor cooling requires a large amount of water as a cooling agent. To save water, the cooling water was modelled to be recycled after every cycle. The annual bioreactor cooling cost was calculated to be $\$ 76,382$. If recycled, the cost of water is reduced to $\$ 6,365 /$ year, saving from the cost of utilities $\$ 1,070,000$, by using less water, than that without recycling.

Similarly, the hexane required for the lipid extraction was assumed to be recycled after each cycle. To design the bioreactor size, the aspect ratio was considered in respect to the diameter and height impact on the aeration rate. A larger diameter would require larger aeration rate, while larger height creates higher hydrostatic pressure. In its turn the hydrostatic pressure determines the size of the compressor. By consulting sources regarding to the scale of the airlift bioreactor used in ICI's Pruteen process, the bioreactor parameters were set as such ( $h: 55.5 \mathrm{~m}, r: 2.4 \mathrm{~m}$ ) to allow a hydrostatic pressure of $4.25 \mathrm{~atm}$, for which a compression ratio of 4 means only one compressor is needed. The compressor was sized accordingly to overcome the hydrostatic pressure and was calculated to deliver $23,952.10 \mathrm{~m}^{3} / \mathrm{h}$ of air at a discharge pressure of $4.25 \mathrm{~atm}$.

Initially a continuous system was also examined, however we considered it is highly unlikely that the maximum cell concentration, used in the draw-fill case, could be maintained with this system, therefore with a lower cell concentration, the lipid production would be similar or worse than the draw-fill case [30]. Continuous processing is normally applied to processes producing extracellular molecules that can then be stripped from the broth, in the case of lipid production this is technically feasible with the latest advances in metabolic engineering, and therefore was addressed in the latter scenario.

\section{Economy of scale}

For a plant containing a single bioreactor only, the lipid selling price calculated was $\$ 1.81 / \mathrm{kg}$. This is comfortably lower than the estimated prices for the more realistic models presented in the literature $[27,31]$. However, the total amount of sugar used is still $7 \times$ less than can be feasibly collected in an area around the plant. As such the effect of economy of scale was assessed for up to 7 airlift bioreactors. For simplicity of calculations the equipment and materials associated with the bioreactor were modified. In particular, the bioreactor number was increased from 1 to 7 along with the air filters, the compressor and its respective cooler, the bioreactor chiller, the pasteuriser and the holding tanks to regulate the downstream processing of deactivated cells were modified accordingly.

Unsurprisingly, the lipid production price changes dramatically with an increased economy of scale (Fig. 2). While the equipment cost increases, the multipliers for FCI and COM absorb the increase in installed equipment cost and even though the utilities are greater, in conjunction with the larger oil production, the price decreases. There is little benefit to increasing beyond 6 bioreactors, and so this was selected as the appropriate largest feasible size of plant. This is a reasonable assumption since previous techno-economic works modelled 10 to 12 stirred tank bioreactors, ranging from 250 to $750 \mathrm{~m}^{3}$ to achieve the targeted annual production.

The share of these bioreactors together on the total equipment cost ranged from 68 to $90 \%$ [31, 32, 46]. What is more, a breakdown of the electricity used for the bioreactor showed that it was $53 \%$ of the total electricity cost [31]. In this study, the cost of one airlift bioreactor was set as $\$ 991,615$, lacking of agitator and electricity costs, therefore not responsible for the biggest impact on the installed equipment cost. The volume modelled is larger than those usually studied and the strain is highly productive. Table 6 shows how the cost of manufacture, FCI, raw materials and utilities are affected by the increased bioreactor number and lipid amount.

\section{Comparison to alternative techno-economic studies}

In one of the original, most detailed studies Koutinas et al. reported prices of $\$ 5.5 / \mathrm{kg}$ oil and $\$ 5.9 / \mathrm{kg}$ for biodiesel for a process that used $\$ 400 / \mathrm{t}$ of glucose 


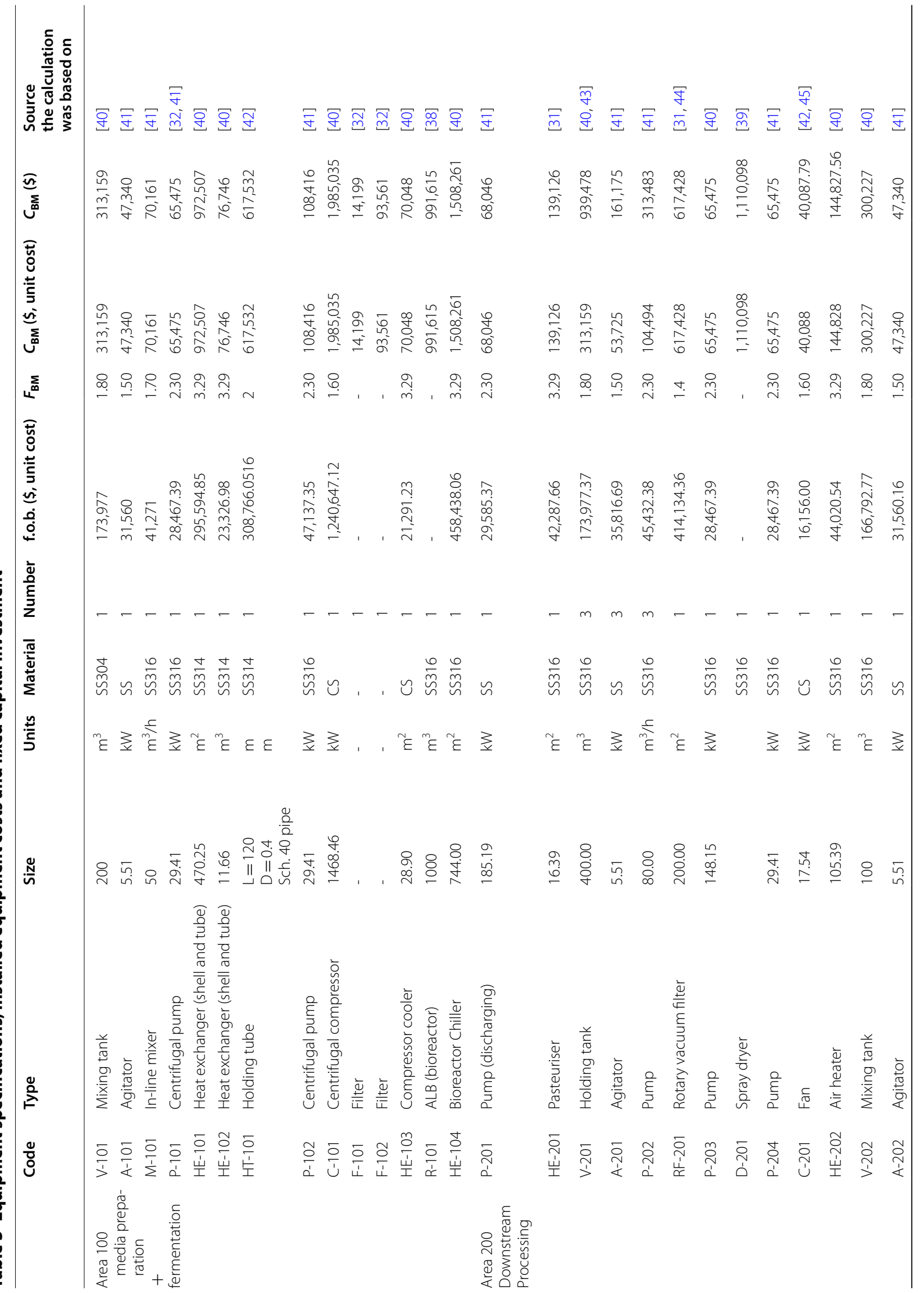




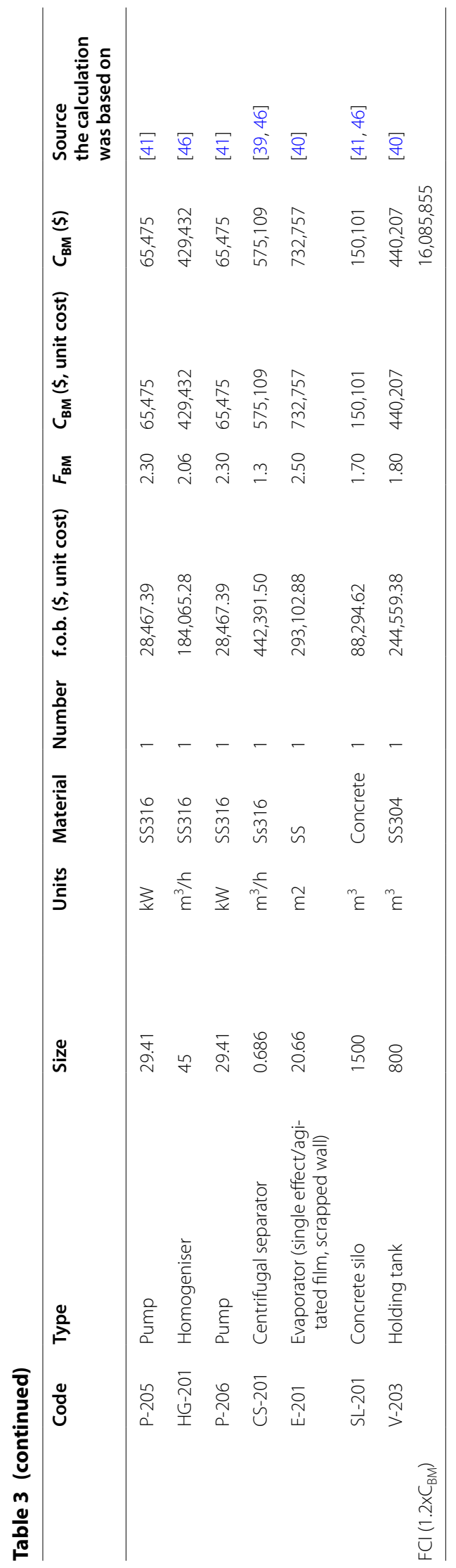


Table 4 Overview of utilities and labour costs

\begin{tabular}{|c|c|c|c|c|c|}
\hline Equipment & Number of equipment & Workers/shift ${ }^{\mathrm{a}}$ & Electricity $(\$ / y)^{a}$ & $\begin{array}{l}\text { Low-pressure steam (\$/ } \\
\text { year) }^{\mathrm{a}}\end{array}$ & $\begin{array}{l}\text { Cooling } \\
\text { water }(\$ / \\
\text { year })^{\mathrm{a}}\end{array}$ \\
\hline V-101 & 1 & 0 & - & - & - \\
\hline A-101 & 1 & 0.5 & 1028.53 & - & - \\
\hline$M-101$ & 1 & 0.3 & 3360 & - & - \\
\hline P-101 & 1 & 0 & 5489.87 & - & - \\
\hline HE-101 & 1 & 0.1 & - & - & - \\
\hline HE-102 & 1 & 0.1 & - & $72,616.55$ & - \\
\hline HT-101 & 1 & 0.1 & - & - & - \\
\hline P-102 & 1 & 0 & $34,567.90$ & - & - \\
\hline$C-101$ & 1 & 0.1 & $274,113.24$ & - & - \\
\hline F-101 & 1 & 0 & - & - & - \\
\hline F-102 & 1 & 0 & - & - & - \\
\hline HE-103 & 1 & 0.1 & - & - & 1105.07 \\
\hline R-101 & 1 & 0.5 & - & - & - \\
\hline HE-104 & 1 & 0.1 & - & - & 6365.18 \\
\hline P-201 & 1 & 0 & $34,567.90$ & - & - \\
\hline HE-201 & 1 & 0.5 & - & $748,448.88$ & - \\
\hline V-201 & 3 & 0 & - & - & - \\
\hline A-201 & 3 & 0 & 3085.6 & - & - \\
\hline P-202 & 3 & 0.2 & $82,962.96$ & - & - \\
\hline$F-201$ & 1 & 0 & - & - & - \\
\hline P-203 & 1 & 0.2 & $27,654.32$ & - & - \\
\hline D-201 & 1 & 0 & 4704 & - & - \\
\hline P-204 & 1 & 0.2 & $34,567.90$ & - & - \\
\hline$C-201$ & 1 & 0.1 & $689,747.40$ & - & - \\
\hline HE-202 & 1 & 0 & - & $698,730.10$ & - \\
\hline T-202 & 1 & 0.5 & 1028.53 & - & - \\
\hline A-202 & 1 & 0 & - & - & - \\
\hline P-205 & 1 & 0 & 1028.53 & - & - \\
\hline HG-201 & 1 & 0.3 & 5489.87 & - & - \\
\hline P-206 & 1 & 0 & 5644.8 & - & - \\
\hline CS-201 & 1 & 0.25 & 5489.87 & - & - \\
\hline E-201 & 1 & 0.3 & - & - & - \\
\hline SL-201 & 1 & 0 & - & $1,168,927.40$ & - \\
\hline T-203 & 1 & 0 & - & - & - \\
\hline Total (\$/y) & & 450,000 & $1,184,425$ & $2,688,723$ & 7470 \\
\hline
\end{tabular}

${ }^{a}$ The costs are related to the total number of equipment, not the unit cost

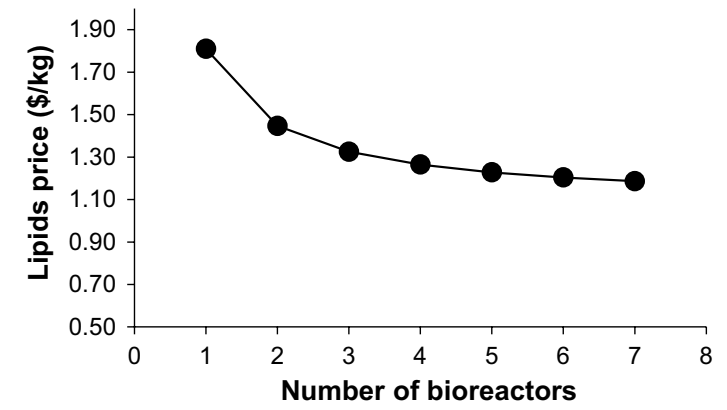

Fig. 2 The impact of economy of scale on the price of lipid $(\$ / \mathrm{kg})$ and produced 10,000 $\mathrm{t}$ /year of oil [31]. They modelled this using $12 \times 250 \mathrm{~m}^{3}$ stirred tank reactors and found that indirect transesterification of lipids to biodiesel was more economical than direct transesterification. Similarly, Braunwald et al. [32], compared $750-\mathrm{m}^{3}$ stirred tank bioreactors to $1260-\mathrm{m}^{3}$ open ponds for an oleaginous yeast cultivation and estimated that in the first case the price was $\$ 2.35 / \mathrm{kg}$ with the fermentation, harvesting and drying costs contributing to the $87 \%$ of the total cost, while the open ponds were cheaper at \$ $1.72 / \mathrm{kg}$ with $43 \%$ contribution to the cost. Despite the 
Table 5 Summary of the raw materials amounts and costs

\begin{tabular}{lclcr}
\hline Raw material & Amount (t/year) & Unit cost $\mathbf{( \$ / k g )}$ & Total cost $(\mathbf{\$} /$ year) & Ref \\
\hline Sugars & $32,208.00$ & 0.14 & $4,509,120$ & \\
Ammonium sulphate & 646.20 & 0.16 & 103,392 & {$[28]$} \\
Hexane & 3907.2 & 0.41 & 1,602 & {$[32]$} \\
Total & & & $4,614,114$ & {$[31]$} \\
\hline
\end{tabular}

higher experimental cell and lipid yields used in the study of Koutinas et al. [31], the cost estimation of the latter study was lower, probably due to the larger bioreactors used. More recently, techno-economic assessment of microbial lipids at different scales (100 t/year and 10,000 t/year), using lignocellulosic feedstocks was assessed. This was modelled for 12 stirred bioreactors $\left(250 \mathrm{~m}^{3}\right)$ and compared to open ponds [27] to assess the variability of capital expenditure and minimum selling price according to scale and various scenarios. For the larger production facility, lower lipid selling price was noted for sucrose $(\$ 4.64-5.41 / \mathrm{kg})$ and wheat straw $(\$ 5.15-5.41 / \mathrm{kg})$ while the pre-treatment required to increase the carbon content of rich feedstocks such as distillers dried grains contributed to the upstream cost.

The lowest estimated price presented to date has been for an integrated refinery concept which assumed a selling price of $\$ 1.3 / \mathrm{kg}$ for lipid and $\$ 0.5 / \mathrm{kg}$ for the defatted biomass, calculated for a single-cell oil produced from molasses at $\$ 99 /$ tonne, as part of an integrated refinery with sugar production. This was calculated by modelling exponential fed-batch fermentations with $11 \times 500 \mathrm{~m}^{3}$ stirred tank bioreactors [46]. The latter lower price was achieved through replacing the stainless steel bioreactor with the cheaper alternative of carbon steel vessel with epoxy lining to reduce the capital cost and by combining in a sugar mill, reducing the cost of the molasses substantially [46]. Though this study lacked the full detail of the previous studies, it is a useful indicator that valorising the defatted biomass can aid in the reduction of the overall lipid price.

In a more recent publication by Koutinas et al., the group produced a slightly lower oil price of $\$ 4.613 / \mathrm{kg}$ for $10,000 \mathrm{t} /$ year production of lipids and estimated the price would be between $\$ 5.8$ for $2000 \mathrm{t} /$ year and $\$ 4.1 / \mathrm{kg}$ for $40,000 \mathrm{t} /$ year production capacity [47]. Their minimum lipid selling price of $\$ 2.5 / \mathrm{kg}$ was estimated for the case of $\$ 0.10 / \mathrm{kg}$ glucose, which is similar to the price of sugars used in this work $(\$ 0.14 / \mathrm{kg})$ and close to the lipid price of the single bioreactor facility, $\$ 1.81 / \mathrm{kg}$ for $\sim 8000 \mathrm{t}$ annual production.

In contrast to all previous studies, this work based the cost estimations on one very large bioreactor, assuming ideal yields and an optimal conversion process. As a costsaving approach, the bioreactor was airlift, while other works used more than ten conventional stirred tanks. Subsequently, the estimated lipid price was lower than that of other techno-economic analyses. The lipid price of $\$ 1.82 / \mathrm{kg}$ was around 3 times lower than that of Bonatsos et al. [47] and Parsons et al. [27] but was closer to the open ponds model $(\$ 1.72 / \mathrm{kg})$ [32]. The similarity of the prices indicates that vessels with low running costs have a big impact on reducing the production cost.

\section{Alternative processing scenarios}

The lowest cost of lipid is reduced to $\$ 1.20 / \mathrm{kg}$ using 6 bioreactors, a $33.7 \%$ reduction in the price. However, a number of other scenarios have been presented in the literature, which have claimed to reduce the price of lipids

Table 6 Summary of lipids price, equipment, utilities cost and raw materials for different bioreactor numbers

\begin{tabular}{|c|c|c|c|c|c|c|c|c|}
\hline $\begin{array}{l}\text { Reactor } \\
\text { number }\end{array}$ & $\begin{array}{l}\text { Production }(t / \\
\text { year) }\end{array}$ & COM (\$) & Oil price $(\$ / \mathbf{k g})$ & $\mathrm{FCl}(\$)$ & COL (\$) & CRM (\$) & CUT (\$) & $\begin{array}{l}\text { Sugars } \\
\text { needed (t/ } \\
\text { year) }\end{array}$ \\
\hline 1 & 8053 & $14,572,474$ & 1.81 & $16,085,855$ & 450,000 & $4,614,114$ & $3,880,618$ & 32,208 \\
\hline 2 & 16,105 & $23,303,062$ & 1.45 & $23,626,689$ & 556,875 & $9,228,227.11$ & $5,023,796$ & 64,416 \\
\hline 3 & 24,157 & $32,018,294$ & 1.33 & $31,167,523$ & 658,125 & $13,842,340.67$ & $6,166,975$ & 96,624 \\
\hline 4 & 32,210 & $40,733,526$ & 1.26 & $38,708,357$ & 759,375 & $18,456,454.22$ & $7,310,154$ & 128,832 \\
\hline 5 & 40,262 & $49,448,758$ & 1.23 & $46,249,191$ & 860,625 & $23,070,567.78$ & $8,453,332$ & 161,040 \\
\hline 6 & 48,315 & $58,163,990$ & 1.20 & $53,790,025$ & 961,875 & $27,684,681.34$ & $9,596,511$ & 193,248 \\
\hline 7 & 56,367 & $66,879,221$ & 1.19 & $61,330,859$ & $1,063,125$ & $32,298,794.89$ & $10,739,689$ & 225,456 \\
\hline
\end{tabular}


substantially. To investigate these claims, a range of scenarios were assessed for the effect on the lipid selling price, these included having access to inexpensive electricity, using a non-sterile process, using a thermotolerant species, using a species that could produce the lipid extracellularly, using wet cell extraction and removing the extraction stage altogether and selling the lipid and cell as one product.

As seen previously, due to the lipids being an intracellular product, there is a range of recovery steps, from which some are costly in terms of equipment and energy consumption. In order to achieve above $95 \%$ lipids recovery and above all steps from cells filtering, drying and disruption [48] should be efficient. The proposed process was reviewed and edited by removing specific downstream steps and consider an alternative end-use for the lipids and/or biomass together.

\section{Effect of electricity price on the lipids cost}

The production of single-cell oil is a high energy process, and as such the cost of electricity has been cited as a major cost contributor in microbial oils production [31]. In this work, the lowest possible price of electricity for industrial use was used, $\$ 0.02 / \mathrm{kWh}$ [49], without necessarily being the cost of electricity in Brazil. To investigate how different prices of electricity affect the selling price, the latter was modelled for prices ranging from $\$ 0.00-$ $0.06 / \mathrm{kWh}$. In this model the lipid price was found to increase by approximately $\$ 0.1 / \mathrm{kg}$ for a $\$ 0.01 / \mathrm{kWh}$ rise in electricity price. Sugarcane bagasse is burned to satisfy the energy requirements of sugar mills and $36.7 \mathrm{kWh}$ of electricity can be generated from a tonne of crushed sugarcane [50]. Design works on bioproduction plants, similarly adjacent to sugarcane mills, consider burning bagasse for electricity generation for increasing revenue or for use in the mill and investigate combined heat and power (CHP) to increase efficiency [51]. Therefore, the surplus electricity from the mill can be directed to cover part or the whole of the electricity demand of the microbial lipids plant, reducing an important cost contributor. It was envisaged that the electricity can be obtained for free if it is subsidised or produced internally. In our presented scenarios, the minimum price reduces to $\$ 1.63$ / $\mathrm{kg}$ for the single bioreactor base case process with zero cost of electricity, however, for the six bioreactor scenario the price is not reduced substantially and the lipid still costs $\$ 1.12 / \mathrm{kg}$ with no electricity cost (Fig. 3).

\section{Non-sterile conditions}

A few experimental works have explored the potential of non-sterile cultivation of oleaginous yeasts to reduce the cost by sterilisation at large scale $[52,53]$. Maintenance of monoculture can be facilitated by adoption of harsh

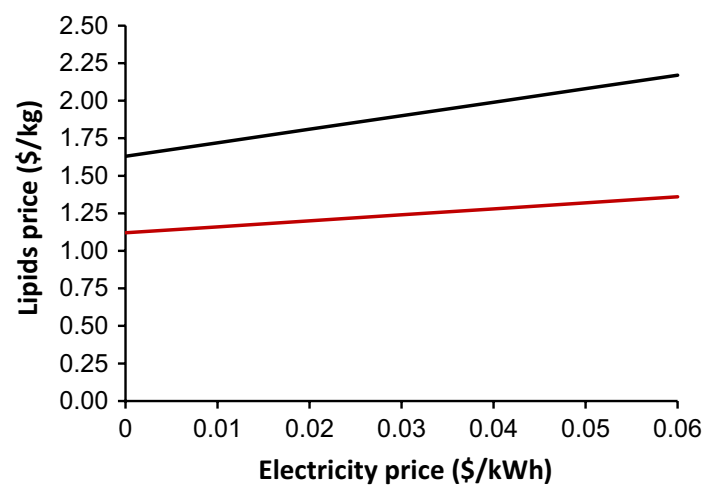

Fig. 3 The impact of electricity prices $(\$ / \mathrm{kWh})$ on the selling price of lipids $(\$ / \mathrm{kg})$ for the one bioreactor scenario (black line) and six bioreactor scenario (red line)

culture conditions, such as low $\mathrm{pH}$ or addition of toxic compounds, selective to the target microorganism. To adapt the model to this hypothetical scenario, the continuous steriliser was removed with its associated steam requirements and it was assumed that the organism was able to secrete antimicrobial compounds and survive in low $\mathrm{pH}$, as previously reported by Santamauro et al. [54].

Removing sterilisation affects $12 \%$ of the installed equipment cost, $11 \%$ of the operating labour and only $2 \%$ of the total low-pressure steam cost. Its removal drops the production cost of lipids from $\$ 1.81$ to $\$ 1.75 / \mathrm{kg}$, for the one-reactor scenario and from $\$ 1.20$ to $\$ 1.19 / \mathrm{kg}$ for the six-reactor scenario (Fig. 4). This is a modest saving, however in addition, it should be noted that removing sterilisation altogether is a rather controversial modification, as possible hardy contaminating species entering with the media will be difficult to get rid of, especially at such large scale. The main microorganism needs to be really robust to remain the dominant population and if the lipids are used in the food industry, relevant regulations would be difficult to meet. It is unlikely that this is a plausible scenario at all, but rather these ultra-robust organisms act as another buffer against contamination alongside conventional strategies.

\section{Thermotolerant strain}

In a similar vein to the non-sterile scenario, thermotolerant microorganisms are an attractive option for bioconversions taking place in environments with higher ambient temperature or for withstanding a rise in the broth temperature due to exothermic metabolic reactions and agitation [55]. By using a microbe able to tolerate higher operating temperatures, the need for cooling is reduced, followed by energy savings and reduction of cooling water requirements for the bioreactor. To apply 


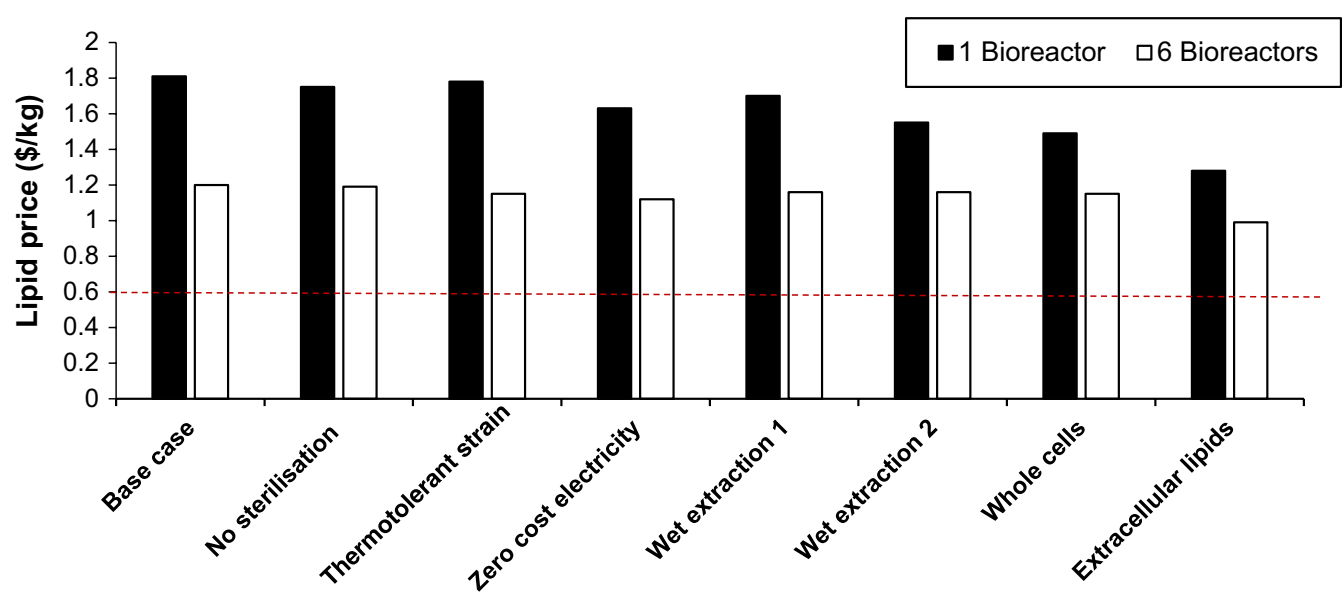

Fig. 4 The impact of alternative processing scenarios on the lipid price $(\$ / \mathrm{kg})$ for the one bioreactor scenario (black) and six bioreactor scenario (white), the red line shows the palm oil price (Nov. 2019). Wet extraction 1 is the case where extraction and stripping columns were used, while wet extraction 2 is the case where the spray dryer was removed

this idea in this process, the chiller and its water requirements were removed. However, elevated temperatures reduce the dissolved oxygen concentration which would also, in reality, reduce the productivity of the yeast. The increase in the evaporation effect, phenomenon preferable in ethanol production as it can be stripped out of the broth more easily, would only increase the amount of water needed for the bioreactor in this case. However, not taking these factors into account, by omitting the chiller, there is a $11 \%$ saving in installed equipment cost but $85 \%$ on the cooling water requirements, as in order to cool a broth of $800 \mathrm{~m}^{3}$, large amounts of water were needed. Nevertheless, the impact on the price of lipids is actually quite low, with the price of the SCO from one reactor dropping to $\$ 1.78 / \mathrm{kg}$ and for 6 bioreactors only being reduced to $\$ 1.15 / \mathrm{kg}$ for the six bioreator scenario (Fig. 4).

\section{Wet cell lipid extraction}

Drying is a costly process as there is a need for an air fan and an air heater to provide the air and heat it to temperatures as high as $150{ }^{\circ} \mathrm{C}$ to dry the cellular paste. Wet lipid extraction has been considered in algal cells [56], where drying and homogenisation are omitted and the lipid extraction and separation take place in an extraction column followed by a stripping column.

Implementation of these stripping columns in this work raised the FCI to $\$ 29,818,363$ and the working capital at $72 \%$ of the one bioreactor scenario for dry cells extraction. However, due to the way the COM is calculated (Eq. 4), the increase in FCI does not greatly affect the price of lipids, which is comparable to the dried extraction process $(1.70 / \mathrm{kg})$. The cost of raw materials altogether remains stable at around $\$ 4,615,000$ as more hexane is now needed (1.7 times more than that used for extraction from dried cells as suggested by the method) according to the NREL process (Table 7) [56]. If the columns are not implemented but only the drier is removed from the base scenario and the rest of the process remains the same downstream of the dryer, the cost drops to $\$ 1.55 / \mathrm{kg}$. That indicates that the drying step

Table 7 The impact of alternative downstream operation sequences on the process cost and lipids price

\begin{tabular}{lllllr}
\hline Scenario & FCI (\$) & CUT (\$) & CRM (\$) & COL (\$) & COM (\$) \\
\hline Base scenario & $16,085,855$ & $3,880,618$ & $4,614,114$ & 450,000 & $14,572,474$ \\
No sterilisation & $14,085,713$ & $3,808,001$ & $4,614,114$ & 425,000 & $14,054,880$ \\
Thermotolerant strain & $14,275,942$ & $3,946,869$ & $4,614,114$ & 450,000 & $14.328,178$ \\
Zero-cost electricity & $16,085,855$ & $2,696,193$ & $4,614,114$ & 450,000 & $13,115,631$ \\
Wet extraction 1 & $29,818,363$ & $1,398,219$ & $4,615,182$ & 325,000 & $13,651,038$ \\
Wet extraction 2 & $14,453,269$ & $2,532,399$ & $4,614,114$ & 400,000 & $12,483,798$ \\
Use of whole cells & $12,718,507$ & $2,694,037$ & $4,612,512$ & 275,000 & $12,027,137$ \\
Continuous extracellular lipids & $19,145,521$ & $1,295,366$ & 104,669 & 300,000 & $10,318,648$ \\
\hline
\end{tabular}


and disruption has a greater impact on the lipids price. When using 6 bioreactors, the price of lipids is $\$ 1.16 / \mathrm{kg}$ if extraction and stripping column are implemented, this is the same as when only the dryer step is removed.

\section{Use of the whole microbial mass as a lipid, protein and nutrient source}

Apart from the lipid droplets, the cell mass contains nutritious molecules, such as carbohydrates and proteins. Oleaginous yeasts were originally grown for their protein content [6] and use of oleaginous biomass produced for aquafeed has also been reported [57]. There has been a growing interest in producing microbial feed ingredients as animal feed additives, using bacteria and yeasts [58]. Using intact cells as a feed ingredient, takes away a large part of the recovery process and most importantly the need to use solvent to extract the lipids. The mixing tank with the hexane, the homogeniser and its electricity, the evaporator and the decanter centrifuge, the low-pressure steam and the labour cost were therefore removed from this scenario. The pasteurising and drying steps are maintained as the first will ensure the cells are not active while the latter will allow for increased shelf life. The cost savings from this process are $21 \%$ in installed equipment cost, $34 \%$ in labour cost, $66 \%$ in utilities and $\$ 1,601$ from omitting hexane from the cost of raw materials.

The overall reduction in the price of lipids drops to $\$ 1.49 / \mathrm{kg}, 17.6 \%$ cheaper than the base process for the one-reactor scenario. This case has value in terms of reducing downstream processing and steps that can compromise the extraction efficiency or affect lipids quality while it removes the need for further treatment and disposal of the defatted cells upon extraction as previously. When using 6 bioreactors the price of lipids drops to $\$ 1.15 / \mathrm{kg}$ (Fig. 4). This is calculated as if the protein and carbohydrate have no value attached to them, and would only really be suitable in the food and surfactant sectors, rather than for fuels.

\section{Development of a continuous process of extracellular lipid production}

If lipids could be produced extracellularly, drying and cell disruption would be unnecessary and the efficiency recovery could be extremely high. Extracellular release of lipids has been reported for yeasts cultivated in acetic acid-media [59, 60]. Cryptococcus curvatus released lipids to the broth when cultivated in media containing more than $20 \mathrm{~g} / \mathrm{L}$ acetic acid. Work in the same research group investigated further this phenomenon, which is a result of compromised integrity of the cellular membrane when subjected to elevated concentrations of the acid [59] and is now the subject of experimental optimisation as an attractive option for lipids recovery [61]. Further to this work, interesting steps have been taken with a genetically transformed $Y$. lipolytica, that was able to produce lipids extracellularly [62] and the bacterium Escherichia coli which has been engineered to release fatty acids [63].

To determine this effect, extracellular lipid production was investigated here by assuming that the yeast culture could be held at maximum biomass $(185 \mathrm{~g} / \mathrm{L})$ for 28 days at a time, and thereafter converting the sugars solely to triglyceride with a weight conversion of $32 \%$ (the molar theoretical maximum). For the recovery of extracellular lipids, a major part of the conventional downstream operation of the proposed process was not required. The cells were assumed to be separated from the broth with a rotary vacuum filter and the supernatant further processed through sedimentation in a mixer/settler, where lipids are separated from the rest of the broth due to density differences. Sedimentation of lipids has been recently reported for recovering sophorolipids at high efficiency [64]. This method reduced the cost of 1 reactor to $\$ 1.28$ / $\mathrm{kg}$ and for the 6 reactor scenario to $\$ 0.99 / \mathrm{kg}$ (Fig. 4).

\section{Reducing the cost of single-cell oils through a biorefinery concept}

Further product valorisation is possible under a biorefinery concept, where all by-products are considered valuable and commoditised. In the first instance, if the lipid extraction process is followed, the defatted cell mass is also a side stream that has value. The lipid-free mass contains proteins and carbohydrates and can be recycled to the fermentation as a yeast extract alternative in the same process $[65,66]$, converted to methane in an anaerobic digester [56] or used as additive to animal feed [31]. For a set revenue of $\$ 14,572,474$ if spent cells were valued at $\$ 0.6 / \mathrm{kg}$ (the same value given by Parsons et al. [27]) the lipid price could further drop to $\$ 1.42 / \mathrm{kg}$ for 1 bioreactor from $\$ 1.81 / \mathrm{kg}$, while for 6 bioreactors the price drops to $\$ 0.81$ from $\$ 1.20 / \mathrm{kg}$.

In other reports, spent cells have been valued at anywhere between $\$ 0.5-2.5 / \mathrm{kg}$ and have been demonstrated to increase the revenue from microbial oil production $[27,31,46]$. Higher revenue is achieved when spent cells are used as animal feed compared to energy generation and can counterbalance other process expenses, such as the cost of raw materials [31]. To investigate this effect, two scenarios were used, where the lipid is extracted from the spent cells and the lipid and spent cells are sold separately versus where the whole cell is sold, without extraction of the lipid, but the non-lipid cell biomass also commands value (Fig. 5). The revenue was held constant, to assess the effect of the increased price of the biomass on the lipid price. Interestingly, the price of the lipid can be reduced substantially, even to $\$ 0$, if a high enough value for the defatted biomass can be obtained. 


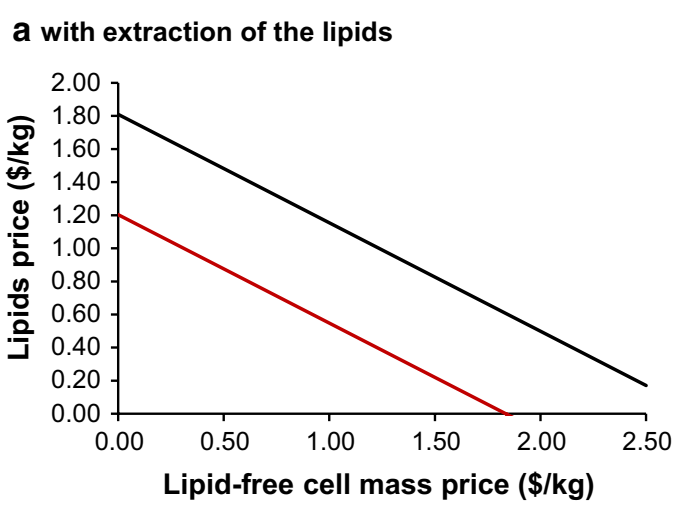

b without extraction of the lipids

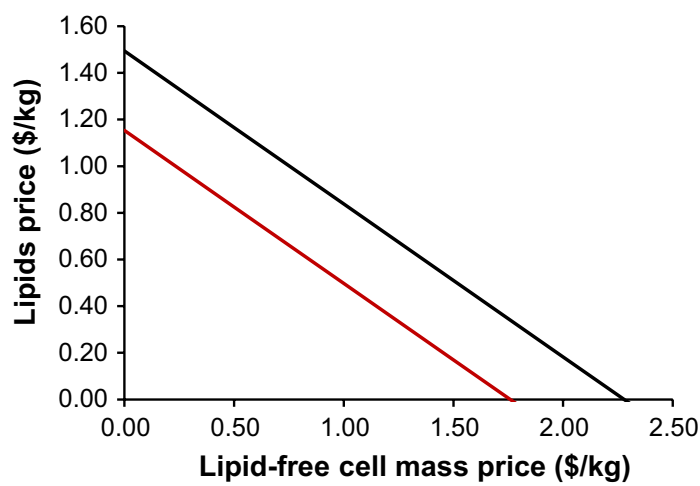

Fig. 5 Impact of the price of lipid-free cells mass $(\$ / \mathrm{kg})$ on the lipids price $\mathbf{a}$ with lipid extraction for the one bioreactor (black line) and six bioreactor scenario (red line), $\mathbf{b}$ without lipid extraction when lipid-free cells and lipids are priced separately but sold together as the whole cell, for the one bioreactor (black line) and six bioreactor scenario (red line)

This demonstrates that a plant producing high-value cell biomass, with lipid as a co-product, could well produce a lipid that competes with palm oil.

A large proportion of oleaginous yeasts are able to produce other small molecules commonly secreted extracellularly. For example, some oleaginous yeasts have been reported to secrete citric acid, concurrently with lipid accumulation and even at larger titres than oil [67-69]. Similarly, other acids from the TCA cycle can be released to the broth [70, 71], pigments from red yeasts [72], 2-phenylethanol [73] and succinic acid [74] have all been reported in literature. If the diversion of carbon from the original sugar source is understood and developed appropriately for scale-up, a valuable product could be obtained adding an additional revenue stream to lipid production.

In this scenario, a generic co-product is assumed with a variable price $(\$ 0-3 / \mathrm{kg}), 40 \%$ carbon by weight (as common acids, such as succinic acid, citric acid and lactic acid contain $\sim 40 \%$ carbon) and the total amount

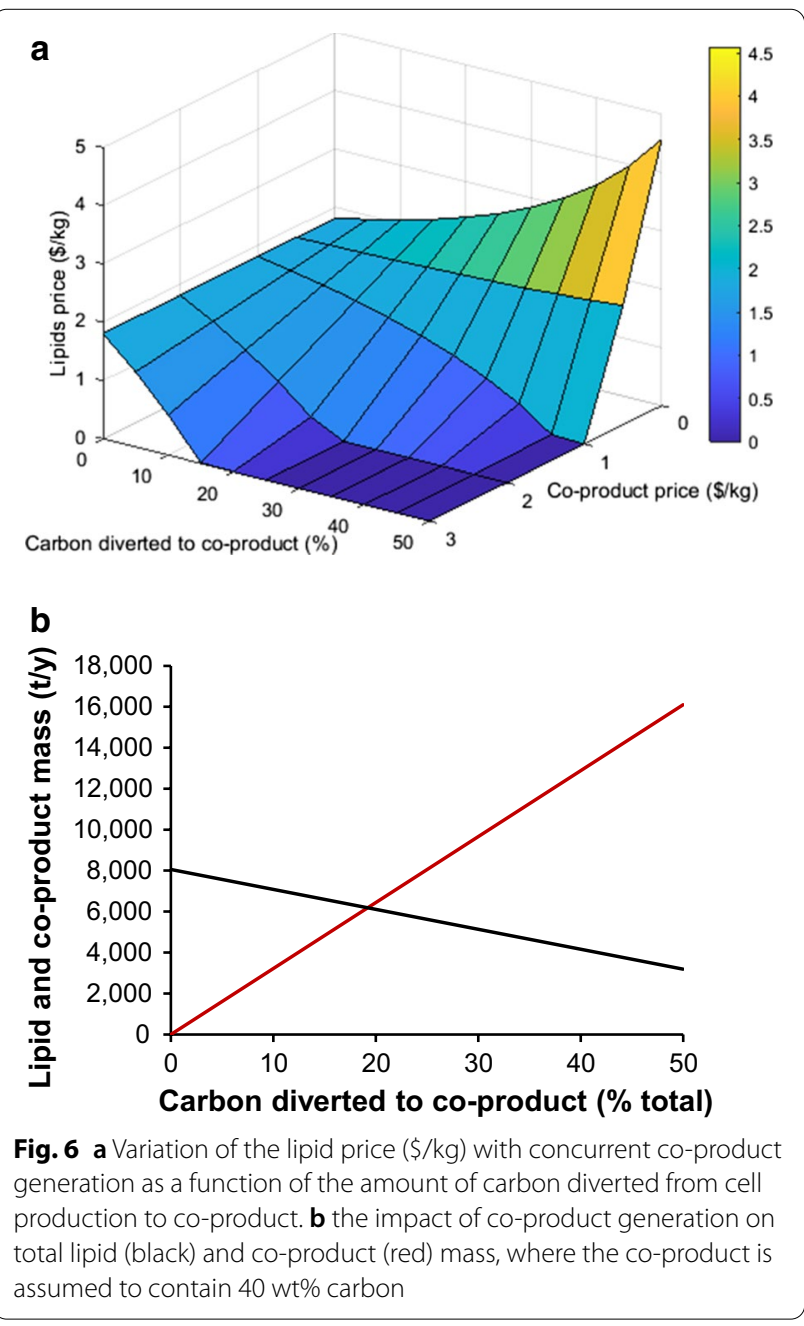

of sugar used in the system was held constant. The total carbon flux was therefore used to calculate the change in the system, with the carbon directed to co-product reducing the amount of yeast biomass and lipid produced from the system (and reducing the $\mathrm{CO}_{2}$ produced as a consequence). For example, in the base case with no co-product, $25 \%$ of the carbon goes to lipids, $41.4 \%$ total biomass (with $16.4 \%$ to lipid-free cells), $8.6 \%$ of the carbon remains unused and $50 \%$ is converted to $\mathrm{CO}_{2}$. In the co-product case, $0-50 \%$ of the original carbon was considered to go to the co-product, taking equal amounts of conversion from the maximum total biomass conversion and from the $\mathrm{CO}_{2}$ for each yield.

To calculate the change in the lipid price, the annual revenue of $\$ 14,572,474$ (where no co-product is produced) was held as constant. The price of lipids was calculated again for different co-product prices ranging from $0.5-3 \$ / \mathrm{kg}$, each for the different yields from 0 to $50 \%$ (Fig. 6). 
If the co-product is valued at $0.5 \$ / \mathrm{kg}$, the increased co-product production, and subsequent reduction in lipid production increases the lipid price slightly, this is because that even though there is less carbon in the coproduct than lipid, $\$ 0.5 / \mathrm{kg}$ is just not enough revenue to compensate for the loss in the higher value lipid. On the contrary, for co-product prices from 1 to $3 \$ / \mathrm{kg}$, the lipids price reduced with decreasing volume, in the most extreme cases the lipid price reaches negative values. This increases the process profitability and it means that lipids are produced for free, along with the co-product, which is now the main product while lipids would be considered as a co-product.

While the extraction of the co-product was not taken into account, as this would be highly dependent on the specific properties, this scenario demonstrates that it would be possible for SCO to compete with terrestrial lipids, if a smaller molecule, with less carbon in was produced alongside the lipid. There is an interesting question here, about whether a full commercial process would want carbon diverted to lipid production, if it could be used in a higher value product, but this could be a viable method of economic lipid production if mandated through policy or if the co-product can simply not be produced in large enough quantities to dominate the production process. However, the practicality of matching the scale of both products needed would be extremely challenging.

\section{Conclusions}

Single-cell oils have the potential to replace terrestrial crops as a feedstock for next-generation biofuels, however, there is a huge uncertainty over whether SCO could ever compete economically with the current state of the art. In this study, the theoretical lowest possible lipid price was determined, by assessing a system to produce oil that is limited only by the amount of feedstock possible to be grown, the biological limitation of a heterotroph and the most efficient chemical plant possible. This still gave a lipid price approximately $2-3$ times higher than palm oil. While it is not feasible to achieve these costs in reality, it would be an engineering impossibility to achieve a cheaper lipid product directly. Further reductions in the price are still possible however, but only through the co-production of a low molecular weight side-product and either the extracellular production of the lipid or the use of the whole cell in a product, though this has limited application for the fuel market.

The point of this paper is therefore to manage expectations in this area, the clear implication for scientists, engineers, policy makers and political decision-makers is that while reported systems could not actually economically compete with terrestrial oils, here we demonstrate that $\mathrm{SCO}$ could start being more competitive as long as more research effort was invested in a targeted approach directed towards these three areas as a matter of priority.

\section{Materials and methods}

\section{Selection of carbon source and plant location}

Sugars are a common carbon and energy source for microbial cultivations and oleaginous heterotrophs can consume them simultaneously or sequentially [75]. Using sugar crops for microbial oil production is simpler than starchy or cellulosic biomass, as pre-treatment and saccharification are not required [76], as such the cheapest source of sugars are still first-generation sugarcane [27]. As such our prospective microbial lipid production plant was assumed to be adjacent to a sugarcane mill from which sugars from sugarcane juice are provided. Hence, lower logistic costs and easy feedstock accessibility facilitate operations. The facility was hypothetically located in the state of Sao Paulo in Brazil, the largest sugar supplier [77]. Sao Paulo hosts the $60 \%$ of Brazilian sugarcane cultivation and accommodates a high density of sugarcane mills [78]. Sugarcane juice contains around $15 \%$ sugars [79] and the juice resulting from the milling process is usually concentrated in order to increase its shelf life prior to fermentation. Data on sugarcane yield and sugar content for the year 2018 were obtained from the relevant USDA report [79] and Raizen's annual report [80]. We imagined that the facility lies in the middle of a circular area of $314 \mathrm{~km}^{2}$ (314,000 ha), of which $10 \%$ was allocated to industrial facilities in the centre, including roads and storage facilities, while the remaining $90 \%\left(282.6 \mathrm{~km}^{2}\right)$ was allocated to sugarcane cultivation (Table 8). This is similar to the system described by Santos et al. for bioethanol production [81]. For this current work processing of sugarcane, extraction and storage of sugars were not considered, and rather were assumed to be in the original price of the sugar. This figure gives a maximum amount of sugar that can be consumed and therefore acts as the limitation on the scale of operation.

\begin{tabular}{lc}
$\begin{array}{l}\text { Table } 8 \text { Hypothetical annual } \\
\text { from the implicit cultivation area } \\
\text { values [79]) }\end{array}$ \\
\hline Parameter & Value \\
\hline Area with sugarcane plantations $\left(\mathrm{km}^{2}\right)$ & $\begin{array}{c}\text { production } \\
\text { USDA yield }\end{array}$ \\
Yield of sugarcane (t/ha) & 282.6 \\
TRS/sugarcane (kg/t) & 65.61 \\
TRS extracted (t/year) & 137.52 \\
\hline
\end{tabular}

Assuming 100\% harvesting efficiency in all steps 


\section{Microbial species}

The literature was reviewed to assign properties to a hypothetical, efficient oleaginous strain. The resulting strain was a blend of properties from several yeasts and was set as an optimistic example to define the best microbial factory. The overall achievable dry cell weight (DCW) was set as $185 \mathrm{~g} / \mathrm{L}$ [17] with a $60.4 \%$ w/w oil content [16] and $1.6 \mathrm{~g} / \mathrm{L} / \mathrm{h}$ lipid productivity [18]. For the sugars-to-lipids conversion the practical maximum yield $25 \% \mathrm{w} / \mathrm{w}$ was adopted [82], while lower than the theoretical maximum yield of $32 \%$, the best literature values tend to cluster in the range of $22-25 \%$ as higher yields are biochemically unfeasible due to carbon diversion to cellular growth and other metabolic routes. To satisfy a carbon balance of $100 \%$, a $50 \% \mathrm{w} / \mathrm{w}$ of carbon was assumed to become $\mathrm{CO}_{2}$ based on calculations on the produced $\mathrm{CO}_{2}$ moles from glucose reported by Davies [38], while $16.39 \%$ of carbon is assigned to lipid-free cell mass. In the base case, no other product was produced from the cultivation with $8 \%$ of the carbon from the original sugars being unconsumed (in line with the majority of studies in this area). Lipids were accumulated according to the following equation:

$$
\begin{aligned}
& 0.232 \mathrm{C}_{6} \mathrm{H}_{12} \mathrm{O}_{6}+0.27 \mathrm{O}_{2}+\mathrm{NH}_{4} \mathrm{SO}_{4} \\
& \quad \rightarrow 0.78 \mathrm{C}_{4} \mathrm{H}_{6.5} \mathrm{O}_{1.9} \mathrm{~N}_{0.7}+0.012 \mathrm{C}_{57} \mathrm{H}_{104} \mathrm{O}_{6} \\
& \quad+\mathrm{CO}_{2}+\mathrm{H}_{2} \mathrm{O}+0.27 \mathrm{SO}_{4}^{-}
\end{aligned}
$$

\section{Bioreactor design}

The operation of bioreactors is complex since sterility is required and, to achieve high oxygen transfer rates, high agitation and aeration rates are needed. High power demand is needed for the function of the agitator and the air compressor [83]. For larger reactors, larger agitators and moving parts are required and that is translated to higher power per unit volume required to achieve the desired oxygenation levels. As such, anaerobic fermentation vessels are significantly larger than those for aerobic processes, with anaerobic bioprocesses reaching volumes of $3,785 \mathrm{~m}^{3}$ and production of 2.5 billion litres of ethanol have been reported [80]. Typically, the number of small and medium size fermenters is larger for an aerobic plant than that of an anaerobic ethanol plant. Likewise, drying and centrifuging the cells are linked to significant electricity consumption during the separation processes [32].

The aeration and agitation needs for aerobic cultivations limit the operational maximum size of stirred tank bioreactors. These large stirred tank reactors are accompanied by higher energy requirements due to the need for aeration, agitation and function of large moving parts [84]. Besides that, bubble column bioreactors (BCR) are less expensive to operate and have $10-20 \%$ lower aeration costs than equal size stirred tank bioreactors (STR) [83]. Moreover, according to Humbird et al., there is little benefit in scaling-up between $500-\mathrm{m}^{3}$ and $1000-\mathrm{m}^{3}$ BCR bioreactors, there is less manpower needed for larger vessels while the range of $500-1000 \mathrm{~m}^{3}$ is suggested for BCR reactors and a maximum of $500 \mathrm{~m}^{3}$ for STR [83]. In a similar screening exercise, $750-\mathrm{m}^{3}$ and $1000-\mathrm{m}^{3}$ bubble column bioreactors have been previously reported by NREL as being the most efficient with no advantage in increasing the size due to the issues of stability for taller reactors and the lower aeration afforded [85].

In this study therefore, to exclude agitator parts from the energy and cost calculations, a $1000-\mathrm{m}^{3}$ airlift bioreactor (ALB) was employed, selected as the hypothetical largest column possible, while still retaining the benefits of the airlift system. The airlift has advantages over the bubble column, as a result of the presence of the riser and downcomer, such as prevention of bubble coalescence, more uniform flow pattern over the focal distribution of energy in the bubble columns and better heat and mass transfer efficiency $[86,87]$. This system was also selected to reduce capital costs substantially over the suggested 12 stirred tank vessels reported previously.

\section{Mode of operation}

Draw-fill cultivation has been applied to oleaginous yeast cultivations, and has achieved the highest cell culture concentrations [16, 30]. Humbird et al. assumed that the oxygen transfer rate should be equal to the oxygen uptake rate and suggested that for optimal aeration cost efficiencies when using bubble column bioreactors the range $50-150 \mathrm{mmol} / \mathrm{L}$ of OUR should be targeted and found that there are larger savings at lower OUR values [83]. Therefore, the broth was assumed to be non-viscous and for efficient operation of the airlift an oxygen uptake rate (OUR) of $50 \mathrm{mmol} / \mathrm{L}$ was chosen as this is at the lower end of the above range, but it is at the upper end for reported experimental studies. For all calculations, physicochemical properties of water were adopted for the fermentation media and broth, as they are aqueous solutions of the nutrients.

\section{Estimation of cost of manufacture}

A 'study estimate' methodology (accuracy $\pm 30 \%$ ) was used for the estimation of the capital expenditure and operating cost [88]. First, the properties of each process stream were defined and the required equipment, such as a heat exchanger or a pump, was designed as such to operate according to these properties. In particular, each equipment purchase cost ('free on-board cost' or f.o.b.) was calculated from equations of the form of Eq. 1, with the purchase cost $\left(C_{p}\right)$ depending on the characteristic size of each piece of equipment, such as volume or area and then 
converted to installed equipment cost $\left(\mathrm{C}_{\mathrm{BM}}\right)$ using the appropriate installation factor $\left(\mathrm{F}_{\mathrm{BM}}\right)$, following methodologies reported in the literature [39,43, 88-90]. When no such equation was available, the cost was estimated using the six-tenths rule (Eq. 2) from existing costed equipment in literature or from graphs relating the cost to the characteristic size from Peters et al. [90] and checked against the online cost estimator [42]. In the end, all installed equipment costs were adjusted to the year 2019, using the Chemical Engineering Plant Cost Index (CEPCI) from the Chemical Engineering Magazine [91], accessed through the University of Bath Library, as per Eq. 3. The cost of manufacture was calculated using Eq. 4 [43]. All prices are expressed as USD (\$) throughout. The cost of waste treatment was not considered in these scenarios:

$$
C_{\mathrm{BM}}=f\left(F_{\mathrm{BM}}, F_{\mathrm{d}}, F_{\mathrm{p}}, F_{\mathrm{m}}\right) C_{\mathrm{p}},
$$

where $C_{\mathrm{BM}}$ is the installed equipment cost, $F_{\mathrm{BM}}$ is the installation factor for the equipment, $F_{\mathrm{d}}$ is a correction factor for the type of equipment, $F_{\mathrm{p}}$ is the correction factor for the operation pressure, $F_{\mathrm{m}}$ is the correction factor for the material as the original equation is applicable to carbon steel only and $C_{\mathrm{p}}$ is the purchase equipment cost:

$$
C_{\mathrm{p}, \mathrm{b}}=\left(\frac{C_{\mathrm{p}, \mathrm{a}}}{X_{\mathrm{a}}^{\mathrm{n}}}\right) X_{\mathrm{b}}^{\mathrm{n}}
$$

where $X$ is the characteristic size of the equipment a and $\mathrm{b}$, respectively, and $\mathrm{n}$ is a superscript that takes values from 0.3 to 0.9 but usually takes the value of 0.6 if the exact superscript is not known (six-tenths rule). $C_{\mathrm{p}, \alpha}$ and $C_{\mathrm{p}}, \mathrm{b}$ is the purchased equipment cost for equipment a and $\mathrm{b}$, respectively,

$$
C_{\mathrm{BM}, \mathrm{b}}=\frac{\mathrm{CEPCI}_{\mathrm{b}}}{\mathrm{CEPCI}_{\mathrm{a}}} C_{\mathrm{BM}, \mathrm{a}} \text {, }
$$

where $C_{\mathrm{BM}, \mathrm{b}}$ is the installed equipment cost for the year $\mathrm{b}$ (unknown), CEPCI is the index for the year a and $\mathrm{b}$, respectively, and $C_{\mathrm{BM}, \mathrm{a}}$ is the known cost for year a (known):

$$
\mathrm{COM}=0.18 \mathrm{FCI}+2.73 C_{\mathrm{OL}}+1.23\left(C_{\mathrm{RM}}+C_{\mathrm{UT}}+C_{\mathrm{WT}}\right),
$$

where $\mathrm{COM}$ is the cost of manufacture, $C_{\mathrm{OL}}$ the labour cost, $C_{\mathrm{RM}}$ the raw materials cost, $C_{\mathrm{UT}}$ the utilities cost and $C_{\mathrm{WT}}$ the cost of waste treatment.

\section{Abbreviations}

ALB: Airlift bioreactor; BCR: Bubble column bioreactor; CEPCl: Chemical Engineering Plant Cost Index; COM: Cost of manufacture; DCW: Dry cell weight; f.o.b.:'Free on-board' cost; FCl: Fixed capital investment; LCA: Life cycle assessment; OUR: Oxygen uptake rate; PFD: Process flow diagram; SCO: Single-cell oils; STR: Stirred tank bioreactor; TEA: Techno-economic analysis; TRS: Total reducing sugars; USDA: United States Department of Agriculture.

\section{Acknowledgements}

This research has been funded by the Industrial Biotechnology Catalyst (Innovate UK, BBSRC, EPSRC) to support the translation, development and commercialization of innovative Industrial Biotechnology processes (EP) N013522/1). In addition, the authors would like to extend their thanks for the invaluable advice from Dr Phil Pienkos (NREL), Dr. Peter Turner (Breakthrough Energy Ventures) and Prof. Ioannis Kookos (University of Patras).

\section{Authors' contributions}

EK acquired the results, analysed and interpreted the results. EK also completed the first draft of the work. SP, CC revised the draft. MM, CC, SP conceived the study, designed the work and acquired the funding for the work.

\section{Funding}

This research has been funded by the Industrial Biotechnology Catalyst (Innovate UK, BBSRC, EPSRC) to support the translation, development and commercialisation of innovative Industrial Biotechnology processes (EP/N013522/1).

\section{Availability of data and materials}

The datasets supporting the conclusions of this article are all included within the article.

\section{Ethics approval and consent to participate}

Not applicable.

\section{Consent for publication}

Not applicable.

\section{Competing interests}

The authors declare that they have no competing interests.

\section{Author details}

${ }^{1}$ Department of Mechanical Engineering, University of Bath, Bath BA2 7AY, UK.

${ }^{2}$ Department of Chemical Engineering, University of Bath, Bath BA2 7AY, UK.

Received: 16 July 2020 Accepted: 21 February 2021

Published online: 04 March 2021

\section{References}

1. OECD/FAO, OECD-FAO Agricultural outlook 2019-2028, 2019th ed., OECD Publishing, Paris, 2019. https://www.oecd-ilibrary.org/agriculture-andfood/oecd-fao-agricultural-outlook-2019-2028_agr_outlook-2019-en.

2. Li Q, Du W, Liu D. Perspectives of microbial oils for biodiesel production. Appl Microbiol Biotechnol. 2008;80:749-56. https://doi.org/10.1007/ s00253-008-1625-9.

3. Sitepu IR, Garay LA, Sestric R, Levin D, Block DE, German JB, BoundyMills KL. Oleaginous yeasts for biodiesel: Current and future trends in biology and production. Biotechnol Adv. 2014;32:1336-60. https://doi. org/10.1016/j.biotechadv.2014.08.003.

4. Papanikolaou S, Aggelis G. Lipids of oleaginous yeasts. Part I: Biochemistry of single cell oil production. Eur J Lipid Sci Technol. 2011;113(8):1031-51. https://doi.org/10.1002/ejlt.201100014.

5. Vasiliadou IA, Bellou S, Daskalaki A, Tomaszewska-Hetman L, Chatzikotoula C, Kompoti B, Papanikolaou S, Vayenas D, Pavlou S, Aggelis G. Biomodification of fats and oils and scenarios of adding value on renewable fatty materials through microbial fermentations: modelling and trials with Yarrowia lipolytica. J Clean Prod. 2018;200:1111-29. https://doi. org/10.1016/j.jclepro.2018.07.187.

6. Ratledge C. Microbial lipids. In: Biotechnol set. Wiley-VCHVerlag GmbH; 2001. p. 133-197. Doi:https://doi.org/10.1002/9783527620999.ch4g.

7. Quinn JC, Davis R. The potentials and challenges of algae based biofuels: a review of the techno-economic, life cycle, and resource assessment modeling. Bioresour Technol. 2015;184:444-52. https://doi.org/10.1016/j. biortech.2014.10.075.

8. Davis R, Aden A, Pienkos PT. Techno-economic analysis of autotrophic microalgae for fuel production. Appl Energy. 2011;88:3524-31. https:// doi.org/10.1016/j.apenergy.2011.04.018.

9. Sills DL, Paramita V, Franke MJ, Johnson MC, Akabas TM, Greene CH, Tester JW. Quantitative uncertainty analysis of life cycle assessment for algal 
biofuel production. Environ Sci Technol. 2013;47:687-94. https://doi. org/10.1021/es3029236.

10. Sitepu I, Selby T, Lin T, Zhu S, Boundy-Mills K. Carbon source utilization and inhibitor tolerance of 45 oleaginous yeast species. J Ind Microbiol Biotechnol. 2014. https://doi.org/10.1007/s10295-014-1447-y.

11. Karamerou EE, Webb C. Cultivation modes for microbial oil production using oleaginous yeasts_a review. Biochem Eng J. 2019;151:107322. https://doi.org/10.1016/j.bej.2019.107322.

12. Parsons S, Allen MJ, Chuck CJ. Coproducts of algae and yeast-derived single cell oils: a critical review of their role in improving biorefinery sustainability. Bioresour Technol. 2020;303:122862. https://doi.org/10.1016/j. biortech.2020.122862.

13. Patel A, Arora N, Mehtani J, Pruthi V, Pruthi PA. Assessment of fuel properties on the basis of fatty acid profiles of oleaginous yeast for potential biodiesel production. Renew Sustain Energy Rev. 2017;77:604-16. https:// doi.org/10.1016/j.rser.2017.04.016.

14. Whiffin F, Santomauro F, Chuck CJ. Toward a microbial palm oil substitute: oleaginous yeasts cultured on lignocellulose. Biofuels Bioprod Biorefining. 2016;10:316-34. https://doi.org/10.1002/bbb.1641.

15. Moni SM, Mahmud R, High K, Carbajales-Dale M. Life cycle assessment of emerging technologies: a review. J Ind Ecol. 2020;24:52-63. https://doi. org/10.1111/jiec.12965.

16. Zhao X, Hu C, Wu S, Shen H, Zhao ZK. Lipid production by Rhodosporidium toruloides $Y 4$ using different substrate feeding strategies. J Ind Microbiol Biotechnol. 2010;38:627-32. https://doi.org/10.1007/s1029 5-010-0808-4

17. Pan J, Kwak M, Rhee J. High density cell culture of Rhodotorula glutinis using oxygen-enriched air. Biotechnol Lett. 1986;8:715-8. https://doi. org/10.1007/BF01032568.

18. Lin J, Shen H, Tan H, Zhao X, Wu S, Hu C, Zhao ZK. Lipid production by Lipomyces starkeyi cells in glucose solution without auxiliary nutrients. $J$ Biotechnol. 2011;152:184-8. https://doi.org/10.1016/j.jbiotec.2011.02.010.

19. Qiao K, Wasylenko TM, Zhou K, Xu P, Stephanopoulos G. Lipid production in Yarrowia lipolytica is maximized by engineering cytosolic redox metabolism. Nat Biotechnol. 2017;35:173-7. https://doi.org/10.1038/ nbt.3763.

20. Qin L, Liu L, Zeng A-P, Wei D. From low-cost substrates to Single Cell Oils synthesized by oleaginous yeasts. Bioresour Technol. 2017;245:1507-19. https://doi.org/10.1016/j.biortech.2017.05.163.

21. Cho HU, Park JM. Biodiesel production by various oleaginous microorganisms from organic wastes. Bioresour Technol. 2018;256:502-8. https://doi. org/10.1016/j.biortech.2018.02.010.

22. Patel A, Mikes F, Matsakas L. An overview of current pretreatment methods used to improve lipid extraction from oleaginous microorganisms. Molecules. 2018;23:1562. https://doi.org/10.3390/molecules23071562.

23. Karamerou EE, Theodoropoulos C, Webb C. Evaluating feeding strategies for microbial oil production from glycerol by Rhodotorula glutinis. Eng Life Sci. 2017;17:314-24. https://doi.org/10.1002/elsc.201600073.

24. Cui Y, Blackburn JW, Liang Y. Fermentation optimization for the production of lipid by Cryptococcus curvatus: use of response surface methodology. Biomass Bioenerg. 2012;47:410-7. https://doi.org/10.1016/j.biomb ioe.2012.09.017.

25. Zhao X, Kong X, Hua Y, Feng B, Zhao Z. Medium optimization for lipid production through co-fermentation of glucose and xylose by the oleaginous yeast Lipomyces starkeyi. Eur J Lipid Sci Technol. 2008;1 10:405-12. https://doi.org/10.1002/ejlt.200700224.

26. Béligon V, Poughon L, Christophe G, Lebert A, Larroche C, Fontanille P. Validation of a predictive model for fed-batch and continuous lipids production processes from acetic acid using the oleaginous yeast Cryptococcus curvatus. Biochem Eng J. 2016;111:117-28. https://doi.org/10.1016/j. bej.2016.01.016.

27. Parsons S, Abeln F, McManus MC, Chuck CJ. Techno-economic analysis (TEA) of microbial oil production from waste resources as part of a biorefinery concept: assessment at multiple scales under uncertainty. J Chem Technol Biotechnol. 2019;94:701-11. https://doi.org/10.1002/jctb.5811.

28. Soccol CR, Dalmas Neto CJ, Soccol VT, Sydney EB, Da Costa ESF, Medeiros $A B P$, Vandenberghe LPDS. Pilot scale biodiesel production from microbial oil of Rhodosporidium toruloides DEBB5533 using sugarcane juice Performance in diesel engine and preliminary economic study. Bioresour Technol. 2017;223:259-68. https://doi.org/10.1016/j.biortech.2016.10.055.
29. Qi G-X, Huang C, Chen X-F, Xiong L, Wang C, Lin X-Q, Shi S-L, Yang D, Chen X-D. Semi-pilot scale microbial oil production by Trichosporon cutaneum using medium containing corncob acid hydrolysate. Appl Biochem Biotechnol. 2016;179:625-32. https://doi.org/10.1007/s1201 0-016-2019-6.

30. Abeln F, Chuck CJ. Achieving a high-density oleaginous yeast culture: comparison of four processing strategies using Metschnikowia pulcherrima. Biotechnol Bioeng. 2019;116:3200-14. https://doi.org/10.1002/ bit.27141.

31. Koutinas AA, Chatzifragkou A, Kopsahelis N, Papanikolaou S, Kookos IK. Design and techno-economic evaluation of microbial oil production as a renewable resource for biodiesel and oleochemical production. Fuel 2014; 116: 566-577. http://www.scopus.com/inward/record.url?eid=2s2.0-84884323183\&partner $\mathrm{D}=40 \& \mathrm{md} 5=\mathrm{ec} 2 \mathrm{~d} 516 \mathrm{~d}$ 91c2dee1f54242e94 adc1f44.

32. Braunwald T, French WT, Claupein W, Graeff-Hönninger S. Economic assessment of microbial biodiesel production using heterotrophic yeasts. Int J Green Energy. 2014. https://doi.org/10.1080/15435075.2014.940957.

33. Indexmundi. 2019; https://www.indexmundi.com/. Accessed 15 Dec 2019.

34. Jones AD, Boundy-Mills KL, Barla GF, Kumar S, Ubanwa B, Balan V. Microbial lipid alternatives to plant lipids BT. In: Balan V, editor. Microbial lipid production: methods and protocols. New York: Springer New York; 2019. p. 1-32. https://doi.org/10.1007/978-1-4939-9484-7_1.

35. Ratledge C, Cohen Z. Microbial and algal oils: do they have a future for biodiesel or as commodity oils? Lipid Technol. 2008;20:155-60. https:// doi.org/10.1002/lite.200800044.

36. Yousuf A, Khan MR, Islam MA, Wahid ZA, Pirozzi D. Technical difficulties and solutions of direct transesterification process of microbial oil for biodiesel synthesis. Biotechnol Lett. 2017;39:13-23. https://doi.org/10.1007/ s10529-016-2217-x.

37. Doran PM. Bioprocess engineering principles. Elsevier Science; 1995.

38. Davies RJ. Yeast oil from cheese whey_-process Development. In. Moreton RS editor. Single cell oil, Longman Scientific \& Technical.1988. p. 99-143.

39. Harrison RG, Todd PW, Rudge SR, Petrides DP. Bioseparations Science and Engineering (2nd Edition). 2015. https://app.knovel.com/hotlink/toc/ id:kpBSEE0004/bioseparations-science/bioseparations-science.

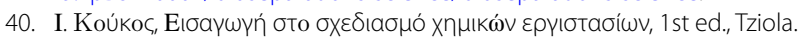
2009. https://www.bookworld.gr/gr/book/bkid/235457/eisagogi-stoschediasmo-chimikon-ergostasion.

41. Humbird D, Davis R, Tao L, Kinchin C, Hsu D, Aden A, Schoen P et al. Process design and economics for biochemical conversion of lignocellulosic biomass to ethanol: dilute-acid pretreatment and enzymatic hydrolysis of corn stover. No. NREL/TP-5100-47764. National Renewable Energy Lab. (NREL), Golden, CO (United States), 2011.

42. West RE, Peters MS, Timmerhaus KD. Equipment costs — plant design and economics for chemical engineers. 2003. http://www.mhhe.com/engcs/ chemical/peters/data/. Accessed 12 Dec 2019.

43. Turton R. Analysis Synthesis and Design of Chemical Processes. 3rd ed. Upper Sadle River: Prentice Hall; 2008.

44. Blanch HW. Biochemical engineering. Boca Raton: CRC Press; 1997.

45. Ulrich GD. A guide to chemical engineering process design and economics. New York: Wiley; 1984.

46. Vieira JPF, lenczak JL, Costa PS, Rossell CEV, Franco TT, Pradella JGC. Single cell oil production integrated to a sugarcane-mill: Conceptual design, process specifications and economic analysis using molasses as raw material. Ind Crops Prod. 2016;89:478-85. https://doi.org/10.1016/j.indcr op.2016.05.046.

47. Bonatsos N, Marazioti C, Moutousidi E, Anagnostou A, Koutinas A, Kookos IK. Techno-economic analysis and life cycle assessment of heterotrophic yeast-derived single cell oil production process. Fuel. 2020;264:116839. https://doi.org/10.1016/j.fuel.2019.116839.

48. Drévillon L, Koubaa M, Nicaud J-M, Vorobiev E. Cell disruption pretreatments towards an effective recovery of oil from Yarrowia lipolytica oleaginous yeast. Biomass Bioenergy. 2019;128:105320. https://doi. org/10.1016/j.biombioe.2019.105320.

49. Global Petrol Prices website. 2019. https://www.globalpetrolprices.com/ electricity_prices/. Accessed 1 Dec 2019.

50. Özüdoğru HMR, Nieder-Heitmann M, Haigh KF, Görgens JF. Technoeconomic analysis of product biorefineries utilizing sugarcane 
lignocelluloses: Xylitol, citric acid and glutamic acid scenarios annexed to sugar mills with electricity co-production. Ind Crops Prod. 2019;133:259-68. https://doi.org/10.1016/j.indcrop.2019.03.015.

51. Nieder-Heitmann M, Haigh KF, Görgens JF. Process design and economic analysis of a biorefinery co-producing itaconic acid and electricity from sugarcane bagasse and trash lignocelluloses. Bioresour Technol. 2018;262:159-68. https://doi.org/10.1016/j.biortech.2018.04.075.

52. Tchakouteu SS, Kopsahelis N, Chatzifragkou A, Kalantzi O, Stoforos NG, Koutinas AA, Aggelis G, Papanikolaou S. Rhodosporidium toruloides cultivated in NaCl-enriched glucose-based media: Adaptation dynamics and lipid production. Eng Life Sci. 2017;17:237-48. https://doi. org/10.1002/elsc.201500125.

53. Moustogianni A, Bellou S, Triantaphyllidou I-E, Aggelis G. Feasibility of raw glycerol conversion into single cell oil by zygomycetes under nonaseptic conditions. Biotechnol Bioeng. 2015;112:827-31. https://doi. org/10.1002/bit.25482.

54. Santamauro F, Whiffin F, Scott R, Chuck C. Low-cost lipid production by an oleaginous yeast cultured in non-sterile conditions using model waste resources. Biotechnol Biofuels 2014; 7: 34. http://www.biote chnologyforbiofuels.com/content/7/1/34.

55. Banat IM, Nigam P, Singh D, Marchant R, McHale AP. Review: Ethanol production at elevated temperatures and alcohol concentrations: part I-Yeasts in general. World J Microbiol Biotechnol. 1998;14:809-21. https://doi.org/10.1023/A:1008802704374.

56. Davis R, Kinchin C, Markham J, Tan E, Laurens L, Sexton D, Knorr D, Schoen $\mathrm{P}$, Lukas J. Process design and economics for the conversion of algal biomass to biofuels: algal biomass fractionation to lipid-and carbohydrate-derived fuel products. No. NREL/TP-5100-62368. National Renewable Energy Lab.(NREL), Golden, CO (United States), 2014.

57. Andlid T, Larsson C, Liljenberg C, Marison I, Gustafsson L. Enthalpy content as a function of lipid accumulation in Rhodotorula glutinis. Appl. Microbiol Biotechnol 1995; 42: 818-825. http://www.scopus.com/inwar d/record.url?eid $=2$-s2.0-0028930674\&partnerlD $=40 \&$ md5 $=$ e4b15 ab74be77319db33a27f5ad1bcf7.

58. Couture JL, Geyer R, Hansen JO, Kuczenski B, Øverland M, Palazzo J, Sahlmann C, Lenihan H. Environmental benefits of novel nonhuman food inputs to salmon feeds. Environ Sci Technol. 2019;53:1967-75. https://doi.org/10.1021/acs.est.8b03832.

59. Huang XF, Shen Y, Luo HJ, Liu JN, Liu J. Enhancement of extracellular lipid production by oleaginous yeast through preculture and sequencing batch culture strategy with acetic acid. Bioresour Technol. 2018;247:395-401. https://doi.org/10.1016/j.biortech.2017.09.096.

60. Cajka T, Garay LA, Sitepu IR, Boundy-Mills KL, Fiehn O. Multiplatform mass spectrometry-based approach identifies extracellular glycolipids of the yeast Rhodotorula babjevae UCDFST 04-877. J Nat Prod. 2016;79:2580-9. https://doi.org/10.1021/acs.jnatprod.6b00497.

61. Huang X-F, Wang Y-H, Shen Y, Peng K-M, Lu L-J, Liu J. Using non-ionic surfactant as an accelerator to increase extracellular lipid production by oleaginous yeast Cryptococcus curvatus MUCL 29819. Bioresour Technol. 2019;274:272-80. https://doi.org/10.1016/j.biort ech.2018.11.100.

62. Ledesma-Amaro R, Dulermo R, Niehus X, Nicaud J-M. Combining metabolic engineering and process optimization to improve production and secretion of fatty acids. Metab Eng. 2016;38:38-46. https://doi. org/10.1016/j.ymben.2016.06.004.

63. Liu H, Yu C, Feng D, Cheng T, Meng X, Liu W, Zou H, Xian M. Production of extracellular fatty acid using engineered Escherichia coli. Microb Cell Fact. 2012;11:41. https://doi.org/10.1186/1475-2859-11-41.

64. Dolman BM, Wang F, Winterburn JB. Integrated production and separation of biosurfactants. Process Biochem. 2019;83:1-8. https://doi. org/10.1016/j.procbio.2019.05.002.

65. Yang X, Jin G, Gong Z, Shen H, Song Y, Bai F, Zhao ZK. Simultaneous utilization of glucose and mannose from spent yeast cell mass for lipid production by Lipomyces starkeyi. Bioresour Technol. 2014;158:383-7. https://doi.org/10.1016/j.biortech.2014.02.121.

66. Yang X, Jin G, Gong Z, Shen H, Bai F, Zhao ZK. Recycling microbial lipid production wastes to cultivate oleaginous yeasts. Bioresour Technol. 2015;175:91-6. https://doi.org/10.1016/j.biortech.2014.10.020.

67. Papanikolaou S, Muniglia L, Chevalot I, Aggelis G, Marc I. Yarrowia lipolytica as a potential producer of citric acid from raw glycerol. J Appl Microbiol. 2002;92:737-44.
68. Moeller L, Strehlitz B, Aurich A, Zehnsdorf A, Bley T. Optimization of citric acid production from glucose by Yarrowia lipolytica. Eng Life Sci. 2007;7:504-11. https://doi.org/10.1002/elsc.200620207.

69. Karamerou EE, Theodoropoulos C, Webb C. A biorefinery approach to microbial oil production from glycerol by Rhodotorula glutinis. Biomass Bioenerg. 2016;89:113-22. https://doi.org/10.1016/j.biomb ioe.2016.01.007.

70. Souza KST, Schwan RF, Dias DR. Lipid and citric acid production by wild yeasts grown in glycerol. J Microbiol Biotechnol. 2014;24:497-506. https ://doi.org/10.4014/jmb.1310.10084.

71. Kot AM, Błażejak S, Kurcz A, Gientka I, Kieliszek M. Rhodotorula glutinispotential source of lipids, carotenoids, and enzymes for use in industries. Appl Microbiol Biotechnol. 2016;100(14):1-15. https://doi.org/10.1007/ s00253-016-7611-8.

72. Saenge C, Cheirsilp B, Suksaroge TT, Bourtoom T. Efficient concomitant production of lipids and carotenoids by oleaginous red yeast Rhodotorula glutinis cultured in palm oil mill effluent and application of lipids for biodiesel production. Biotechnol Bioprocess Eng. 2011;16:23-33. https:// doi.org/10.1007/s12257-010-0083-2.

73. Chantasuban T, Santomauro F, Gore-Lloyd D, Parsons S, Henk D, Scott RJ, Chuck C. Elevated production of the aromatic fragrance molecule, 2-phenylethanol, using Metschnikowia pulcherrima through both de novo and ex novo conversion in batch and continuous modes. J Chem Technol Biotechnol. 2018;93:2118-30. https://doi.org/10.1002/jctb.5597.

74. Li C, Ong KL, Yang X, Lin CSK. Bio-refinery of waste streams for green and efficient succinic acid production by engineered Yarrowia lipolytica without pH control. Chem Eng J. 2019;371:804-12. https://doi.org/10.1016/j. cej.2019.04.092.

75. Cui Y, Liang Y. Sweet sorghum syrup as a renewable material for microbial lipid production. Biochem Eng J. 2015;93:229-34. https://doi. org/10.1016/j.bej.2014.09.013.

76. Cheng $\mathrm{M}-\mathrm{H}$, Huang $\mathrm{H}$, Dien BS, Singh V. The costs of sugar production from different feedstocks and processing technologies. Biofuels Bioprod Biorefining. 2019;13:723-39. https://doi.org/10.1002/bbb.1976.

77. De Oliveira Bordonal R, Carvalho JLN, Lal R, de Figueiredo EB, De Oliveira BG, La Scala N. Sustainability of sugarcane production in Brazil. A review. Agron Sustain Dev. 2018;38:13. https://doi.org/10.1007/s1359 3-018-0490-x.

78. Uriarte M, Yackulic CB, Cooper T, Flynn D, Cortes M, CrkT, Cullman G, McGinty M, Sircely J. Expansion of sugarcane production in São Paulo, Brazil: implications for fire occurrence and respiratory health. Agric Ecosyst Environ. 2009;132:48-56. https://doi.org/10.1016/j.agee.2009.02.018.

79. Barros S. USDA GAIN Report—Brazil Sugar Annual. 2019. https://apps. fas.usda.gov/newgainapi/api/report/downloadreportbyfilename?filen ame=Sugar Annual_Sao Paulo ATO_Brazil_4-15-2019.pdf (accessed December 12, 2019).

80. Raizen annual report 2018/2019. 2019. https://www.raizen.com.br/relat orioanual/1819/pdf/raizen-RA20182019-en.pdf. Accessed 22 Nov 2019.

81. Santos Cl, Silva CC, Mussatto SI, Osseweijer P, van der Wielen LAM, Posada JA. Integrated 1st and 2nd generation sugarcane bio-refinery for jet fuel production in Brazil: Techno-economic and greenhouse gas emissions assessment. Renew Energy. 2018;129:733-47. https://doi.org/10.1016/j. renene.2017.05.011.

82. Yang Y, Hu B. 21-Bio-based chemicals from biorefining. In: K.B.T.-A. in Waldron B editor. lipid and wax conversion and utilization. Woodhead Publishing; 2014. p. 693-720.

83. Humbird D, Davis R, McMillan JD. Aeration costs in stirred-tank and bubble column bioreactors. Biochem Eng J. 2017;127:161-6. https://doi. org/10.1016/j.bej.2017.08.006.

84. Van Brunt J. Fermentation economics. Bio/Technol. 1986;4:395-401. https ://doi.org/10.1038/nbt0586-395.

85. Crater J, Galleher C, Lievense J. Consultancy on large-scale submerged aerobic cultivation process design-final technical report, 2017.

86. Wang S-J, Zhong J-J. Chapter 6-Bioreactor Engineering. In: Yang RR, editor. Bioprocessing for value added. Amsterdam: Elsevier; 2007. p. 131-61. https://doi.org/10.1016/B978-044452114-9/50007-4.

87. Merchuk J. Why use air-lift bioreactors? Trends Biotechnol. 1990;8:66-71. https://doi.org/10.1016/0167-7799(90)90138-N.

88. 9th Edition Perry's Chemical engineers' handbook, perry's chemical engineers' handbook, 9th Edition, 9th edition, McGraw-Hill Education, 
New York; 2019. https://www.accessengineeringlibrary.com/content/ book/9780071834087.

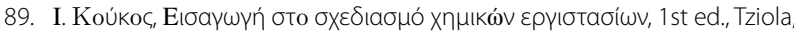
2009.

90. West RE, Peters MS, Timmerhaus KD. Plant design and economics for chemical engineers. 5th ed. New York: McGraw Hill; 2003.

91. Chemical Engineering Magazine. 2019. https://www.chemengonline. com/pci-home. Accessed 12 Dec 2019

\section{Publisher's Note}

Springer Nature remains neutral with regard to jurisdictional claims in published maps and institutional affiliations.
Ready to submit your research? Choose BMC and benefit from:

- fast, convenient online submission

- thorough peer review by experienced researchers in your field

- rapid publication on acceptance

- support for research data, including large and complex data types

- gold Open Access which fosters wider collaboration and increased citations

- maximum visibility for your research: over 100M website views per year

At BMC, research is always in progress.

Learn more biomedcentral.com/submissions 